\title{
Influential indicators of citizenship sports in metropolitan areas of Iran
}

Bahareh Abbasi

PhD Student in Sports Management, Islamic Azad University, Isfahan Branch (Khorasgan), Isfahan, Iran.

Rasool Nazari

*Associate Professor of Sports Management, Islamic Azad University, Isfahan Branch (Khorasgan), Isfahan, Iran. (Corresponding Author) nazarirasool@yahoo.com

\section{Marjan Saffari}

Assistant Professor of Sports Management, Department of Sports Science, Tarbiat Modares University, Tehran, Iran.

Received: 2020/10/05

Accepted: 2021/03/01

Doi: 10.52547/ijhehp.9.2.115

\begin{abstract}
Background and Objective: Citizenship sport is a social phenomenon that guarantees the mental health of human beings and is an important factor in improving their quality of life. The aim of this study is to determine the effective indicators of citizenship sports in metropolitan areas of Iran.
\end{abstract}

Materials and Methods: The present study has a hybrid (qualitative-quantitative) approach. In the qualitative stage, semi-structured interviews with the participation of 20 experts and analysis of contractual content and coding were used. In a quantitative stage, a researchermade questionnaire was used in a 5-point Likert scale with the participation of 15 experts and inferential statistics in the Delphi method. The method of sampling was the selection of experts in the research in a targeted manner and by the method of snowball and with the criterion of executive and operational records or having scientific and research records and theorizing in the field of citizen sports.

Results: By coding and analyzing the content in the qualitative section, 201 open-source codes were extracted and categorized into indicators. The indicators were shared in the form of a questionnaire by Delphi method and the consensus of experts after three rounds indicated that 20 effective indicators of citizenship sports It was determined in the metropolises of Iran. These include motivational factors, needs assessment of public participation, identification of knowledge capacities, decentralization and segmentation of social strata and financial power, managerial stability, unified and centralized urban management, comprehensive and codified planning, information, awareness and improvement of cognitive factors, qualification and Efforts to specialize, coordinate and synergize in the country, integration and macro structure, financial support, creating the right understanding and attitude, setting and changing protection and development laws, active urban transportation, easy access, cheap and safe, availability Necessary infrastructures, increasing public participation, expressing the attractions of sports and the surrounding environment, expressing the socio-cultural benefits of sports, expressing the health and well-being benefits of the community, are 20 indicators of the factors influencing the sports of Iranian metropolitan cities.

Conclusion: With proper urban planning and management and taking into account the 20 identified factors, citizenship sports in the metropolises of Iran will achieve sustainable development and lead to healthy communities and the growth of citizens in cultural, social, economic, political and technological dimensions.

Keywords: Leisure, Delphi method, Physical activity, Sport for all, Public sport.

Paper Type: Research Article.

Citation (Vancouver): Abbasi B, Nazari R, Saffari M. Influential indicators of citizenship sports in metropolitan areas of Iran. Iran J Health Educ Health Promot. Summer 2021;9(2): 115-132.

Citation (APA): Abbasi B., Nazari R., Saffari M. (Summer 2021). Influential indicators of citizenship sports in metropolitan areas of Iran. Iranian Journal of Health Education \& Health Promotion., 9(2), 115-132. 


\section{شاخصهاى تأثيركذار ورزش شهروندى در كلان شهرهاى ايران}

\section{جكيده}

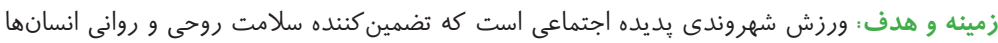

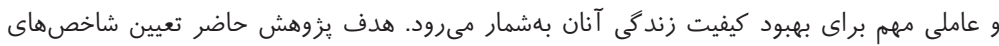

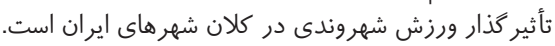

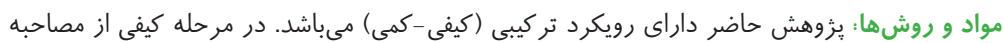

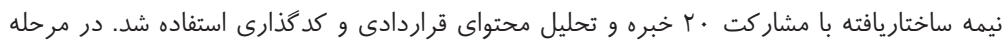

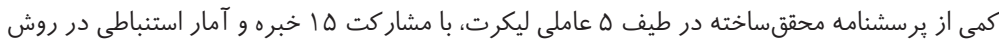

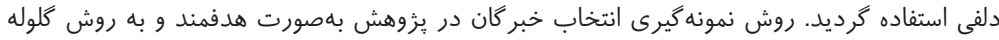

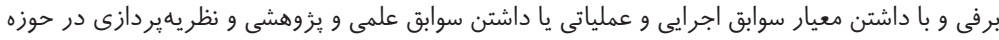
ورزش شهروندى بوده است.

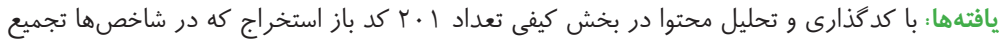

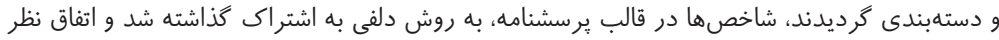

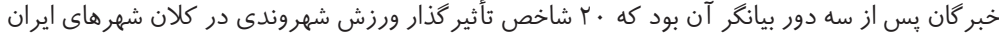

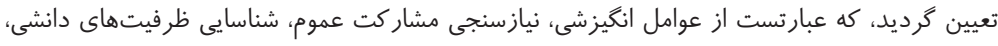

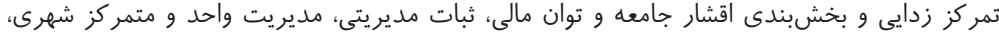

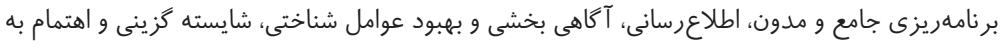

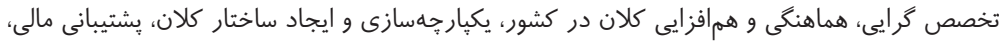

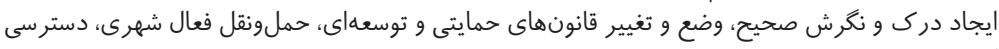

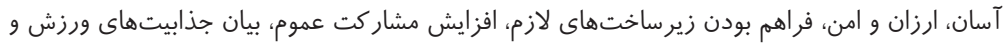

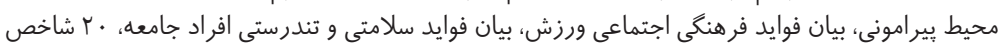

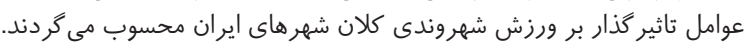

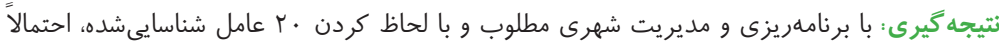

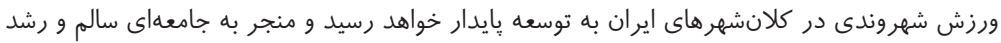

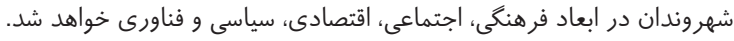

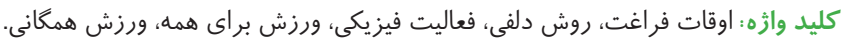

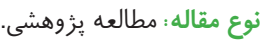

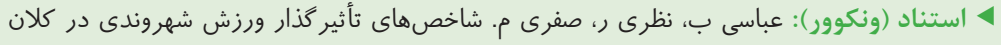

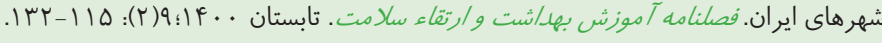

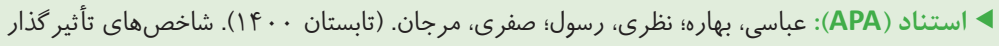

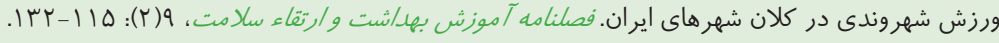

دانشحوى دكترى مديريت ورزشي، دانشكاء آزاد اسلامى، واحد اصفهان (خوراسگان)، اصفهان، ايران . دان. دان.

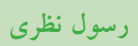

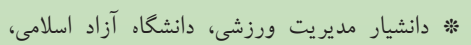

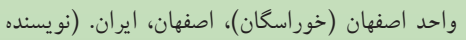
nazarirasool@yahoo.com_

مسئول)

مر جان صفارى استاديار مديريت ورزشى، كروه علوم ورزشى، دانشكا. تربيت مدرس، تهران، ايران.

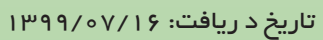

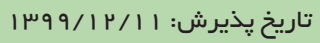


آمادگى جسمانى، كاهش وزن و افزايش قدرت بدنى است. فوايد

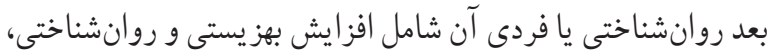

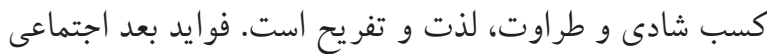

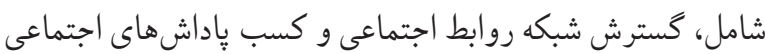
است (9). امروزه ماشينى شدن فعاليتها در جوامع سبب كم تحركى

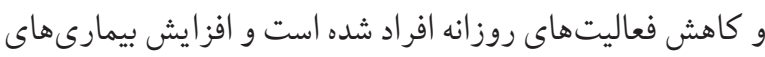

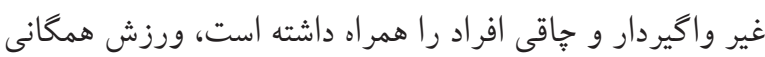

راهكارى ارزان، در دسترس، فراخير، مؤثر و كارا است ( • (1).

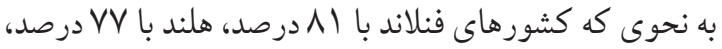

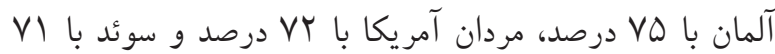

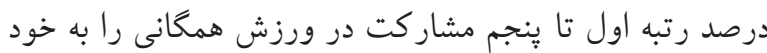

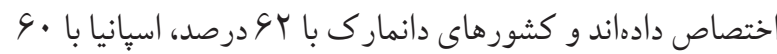

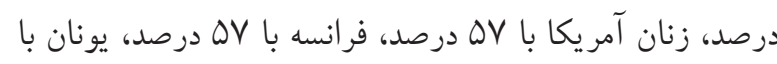

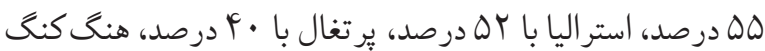

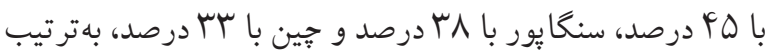

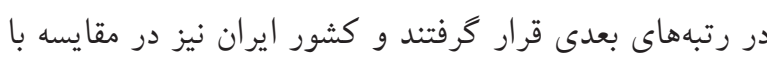

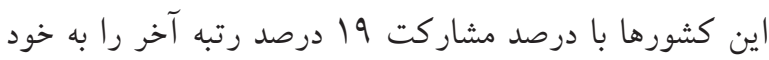

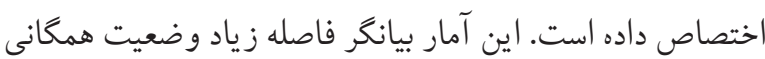
شدن ورزشهاى تفريحى بين ايران و كشورهاى منتخب را نشان

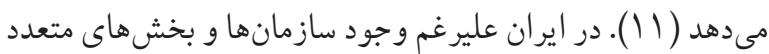

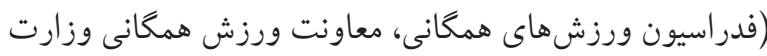

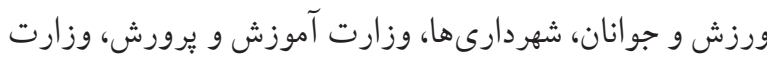
علوم، تحقيقات و فناورى و ...) كه هر كدام خود را به نوعى در قبال ورزش همخانى مسئول مىدانند، متأسفانه تعداد شركت كنند گان

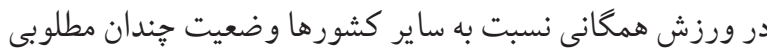

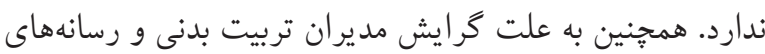

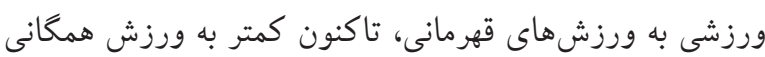

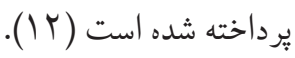

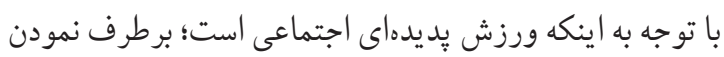

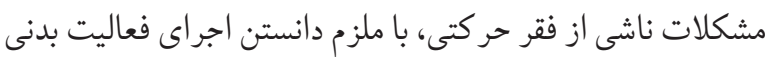

داشتن زندكى شاد، سالم و بلند مدت آرزوى اكثر افراد است ( (1). با اين وجود، فراد در فعاليت بدذى منظم مشاركت محدودى دارند و بى تحرى ردى

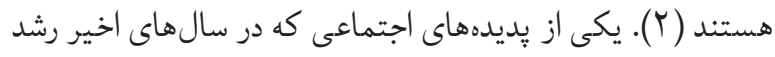

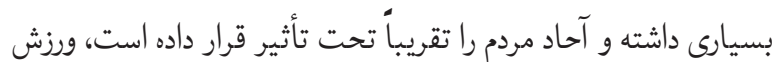
است كه مى تواند سهم بهسزايى در مرتفع ساختن مشكلات حركتى دردي

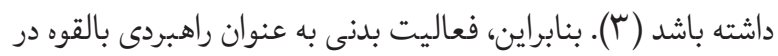

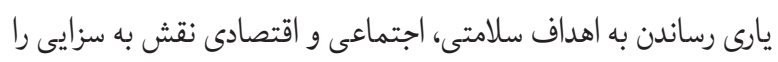

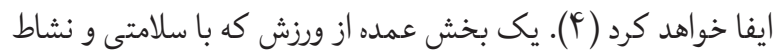

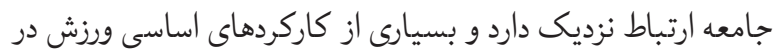

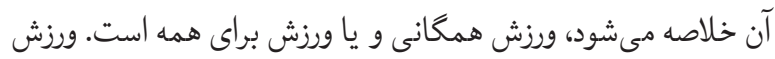

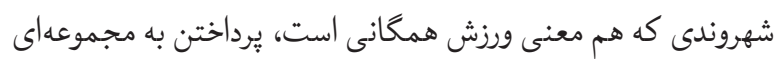

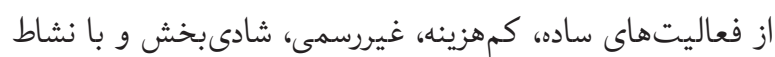
است كه امكان شركت در آنها براى همه افراد وجود داشته باشد. ورزش شهروندى نقش مهمى در ساخت زيربناى جامعه شهرى دارد. آنجه فصل تمايز ورزش شهروندى با ديخر ورزش هاست، شيوه ورود نهاخ به عرصه ورزش و حمايتها و يشتيبانى نرم|فزارى و سختافزارى به براى تحقق اين ورزش است. درصد بالايى از شهروندان، هر سال

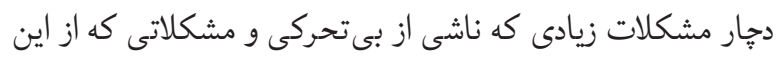

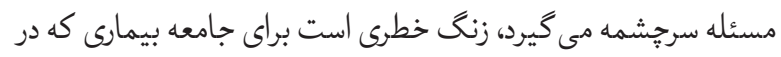
سال هاى آينده خواهيم داشت (ه)؛ نداشتن فعاليت فيزيكى به عنوان

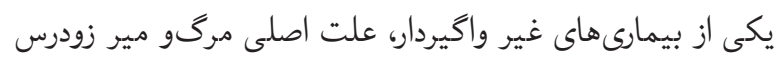
در سراسر جهان است (9). فلسفه ورزش همعانى تشويق شهروندان

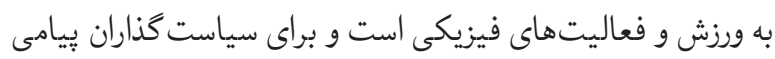

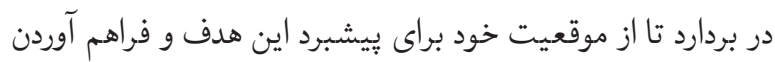

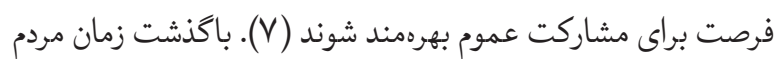

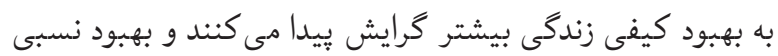

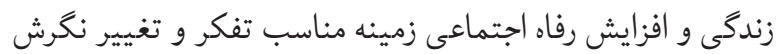

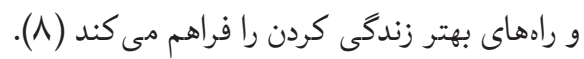

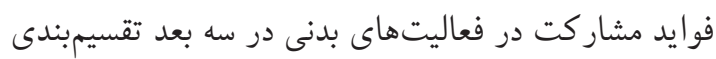

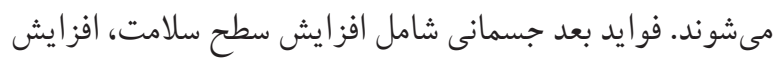


هر دو قشر دانشخاهى و اجرايى موضوعى است كه بر غناى مطالعه

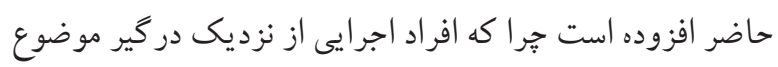

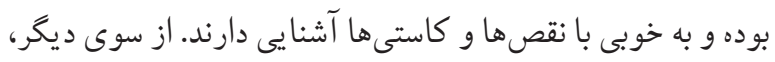

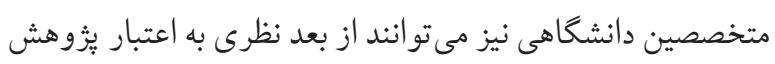

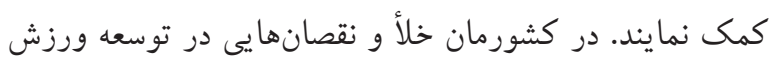

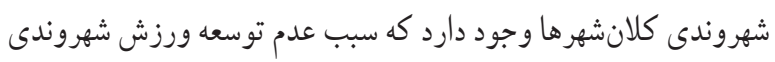
و افزايش مشار كت عموم شهروندان به ورزش شده است؛ اين در

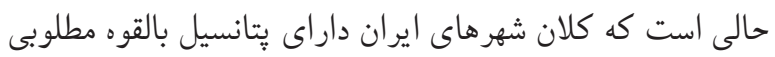

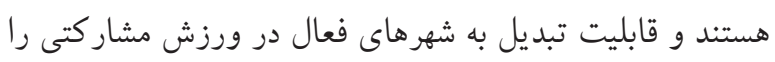

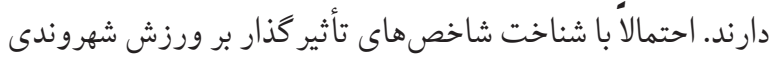

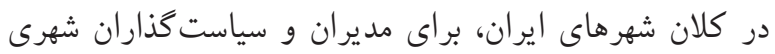

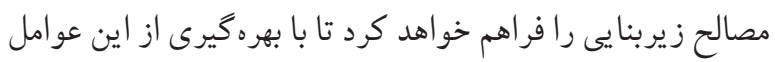
و برنامهريزى كلان در راستاى هريك از اين شاخصها، توسعه شهر

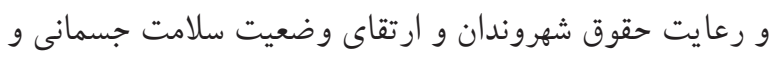

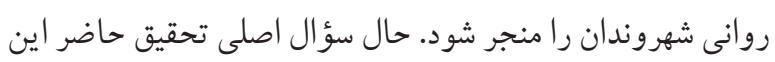

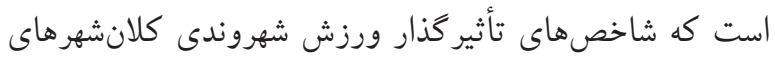

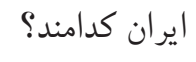

مواد و روش ها اين يُوهش با رويكرد تحقيق تركيبى (كيفى-كمى) در دو مرحله

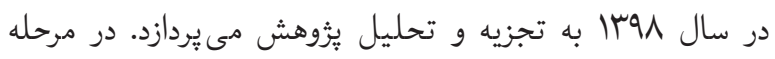

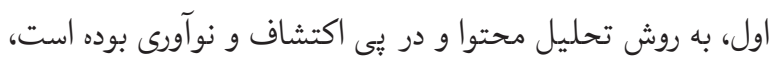
يُزوهش حاضر با استفاده از مصاحبه عميق و نيمه ساختاريافته به وديه

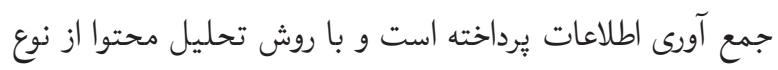

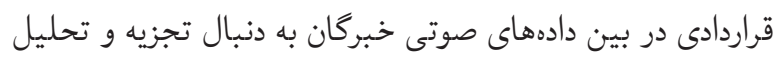

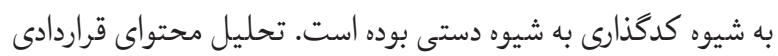

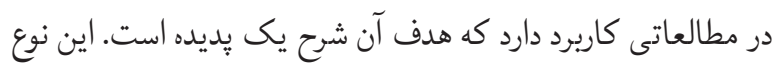
طرح، اغلب هنگامى مناسب است كه نظريههاى موجود يا ادبيات

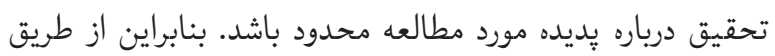

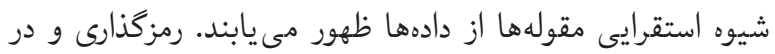

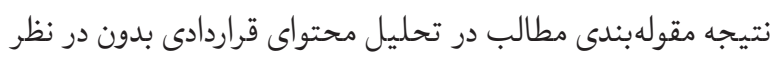

و ورزش در زندكى روزمره دوام جامعه را سبب خواهد شد و با رعايت بهداشت جسمى و روحى، شادابى جامعه تقويت مى شود.

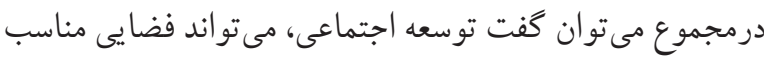
برنامهريزى و مشاركت عموم مردم در ورزش همكانى و نهادينه

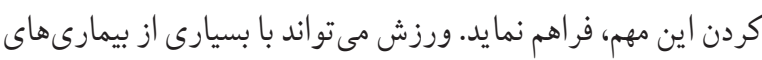

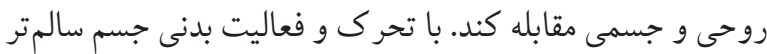
و روح شادابتر خواهد شد و مشكلات روزمره نيز كمتر مىتواند بر جسم و روان مستولى شود (11).

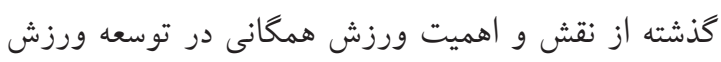

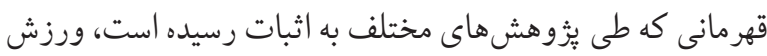

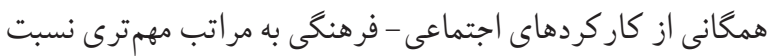

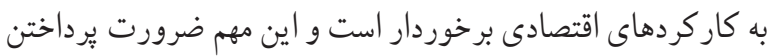
به اين مقوله و توسعه آن را در سطح كشورى كه درحال توسعه به بهد است، به ذهن مى آورد. لذا بايد به دنبال الحويى به منظور نهادينه

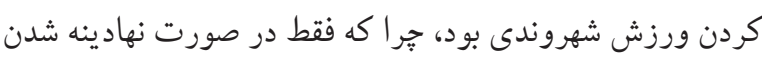
آن است كه مىتوان شاهد تغييرات سازنده آن بر روند توسعه كشور

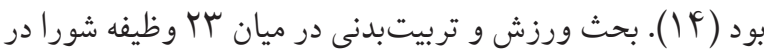

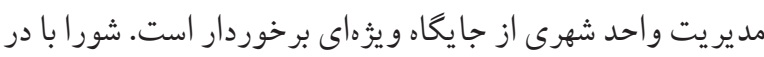

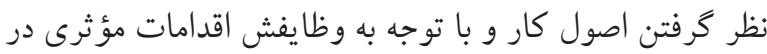

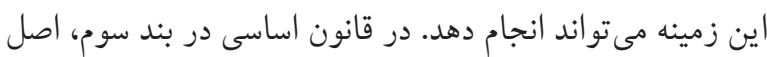
سوم، دولت مكلف است خدمات ورزشى رايكان در اختيار عموم

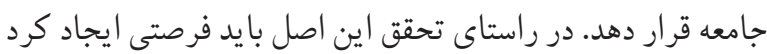

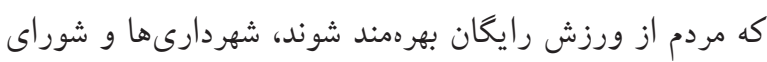
اسلامى شهرها با توسعه ورزش شهروندى، آغاز گر راهى خوز خواهند

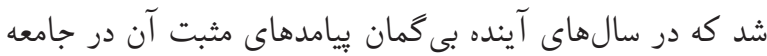

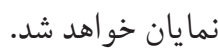
با مراجعه به ادبيات حوزه ورزش شهروندى ايران مشاهده

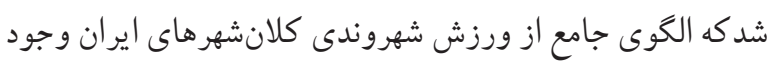
ندارد. علت استفاده از روش كيفى تحليل محتوا عرفى (قراردادى)

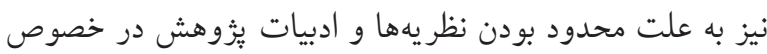
ورزش شهروندى بوده است. مطالعه حاضر در استفاده از نظرات 
يذيرى و قابليت اطمينان بوده و مورد تائيد مىباشد. به نحوى كه در

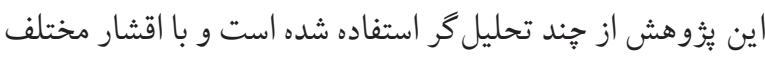
دركير در حوزه شهروندى مصاحبه انجام شده و به نحو مطلوبى از شيوههاى جمع آورى اطلاعات مختلف مصاحبه، كتابخانهاى و مطالعه اسناد بالادستى براى رعايت مقبوليت يزوهش استفاده شده

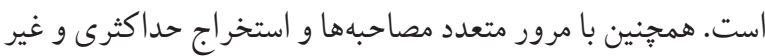
تكرارى مطالب، سعى بر رعايت انتقال يذيرى شد و نيز براى رعايت تائيديذيرى يُّوهش، تمام روندها و مسير تصميمات در طى يُزوهش در كزارش بيان گرديد و نيز از حضور حداكثرى همكاران گروه يُّوهش استفاده شده است. براى ارزيابى قابليت اطمينان يثوهش،

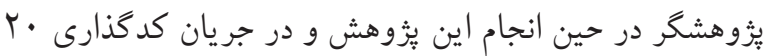
درصد مصاحبهها را بهعنوان نمونه در يك فاصله دو هفتهاى، مجدد مورد كدگذارى قرارداد. با مراجعه به كدهاى اوليه استخراج شده از مصاحبهها و كدهاى مجدد مشخص كرديد كه يايايى باز آزمون مصاحبه هاى اين يثوهش برابر NV/ • است. با توجه به اينكه ميزان يايايى بيشتر از • V/ • است بنابراين، كد گذارىها قابليت اطمينان را دارا هستند (IV) (IV). در مر حله دوم، با رو يكرد كمى و با هدف رسيدن به اتفاق نظر خبر گان و تعيين شاخصهاى حاصل از تحليل محتواى مصاحبهها در مرحله قبل انجام گرفته است، براى جمع آورى اطلاعات از يرسشنامه محقق ساخته كه حاصل مطالعه كيفى در مرحله قبل بوده است در قالب هr سؤال با طيف ه عاملى ليكرت (خيلى

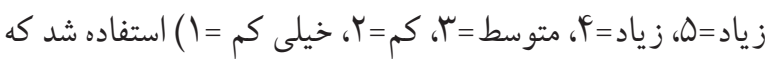
روايى صورى يرسشنامه با استفاده از كارشناس حوزه ادبيات فارسى مورد بازنخرى و تائيد قرار گرفته است و روايى محتوايى سئو الات يرسشنامه توسط خبر گان و كارشناسان اين حوزه به صورت كيفى مورد بررسى، بازنكرى و مورد تائيد قرار گرفت و با توجه به اينكه اين برسشنامه در قالب تكنيك دلفى مورد بازنگرى، ويرايش و تصحيح قرار گرفته است به روايى كيفى بسنده شده است. يس از آماده سازى برسشنامه در بين ها شر كت كننده از خبر گان با استفاده از روش دلفى به اشتر اك گذاشته شد. روش انتخاب خبر گان در اين
داشتن هيج ييشينه تئوريكى، هـزمان با مطالعه متن يا مصاحبه آغاز مىشود و با توجه به موضوع، مرحله به مرحله به تعيين واحد معناو فشرده ساختن آن تا تعيين رمز يرداخته مىشود و در صورت داشتن زمينه مشترك، رمزها ادغام و مقولهها را تعيين مى كنند و سيس مفهوم كلى از جمعبندى مقولهها حاصل مىشود (01). در ادبيات رايج كشور ايران اصطلاح كلان شهر معادل مادرشهر است و به شهرهايى اطلاق مىشود كه حداقل يك ميليون نفر جمعيت داشته داشته باشند؛ در حال حاضر شهرهاى تهران، مشهد، اصفهان، كرج، شيراز، تبريز، قم و اهواز، زاهدان، كرمان، اروميه به صورت رسمى كلان شهر محسوب مى شوند (19). روش انتخاب خبرگان نيز به صورت هدفمند و گلوله برفى و معيار انتخاب مشاركت كنندگان داشتن سوابق اجرايى و عملياتى يا داشتن سوابق علمى و بيزوهشى و نظريه يردازى در حوزه ورزش شهروندى بوده است كه از تعداد كلان شهر انتخاب گرديدند و به گونهاى انجام گرديد كه مصاحبهها r · زان بان رسيدن به اشباع نظرى ادامه يافت و درنهايت با تعداد شركت كننده از خبركان مصاحبه انجام شد. تعداد fI مصاحبه به صورت حضورى و مابقى آن به صورت تلفنى انجام و با رضايت كامل و تعهد عدم انتشار مستقيم صوت مصاحبه شوندگان انجام كرديد و به طور متوسط مدت هر مصاحبه يك ساعت و ده دقيقه بود. سؤالات اوليه مصاحبهها نيز حاصل مطالعات و يزوهشهاى موجود، در قالب •ا سؤال باز تدوين گرديد و با انجام هر مصاحبه با نظر صاحبنظران و خبرگان، ويرايش و تكميلتر كرديد. (1) از نظر شما، محركهاى اصلى (نشانهها) كه مسئولان را متوجه

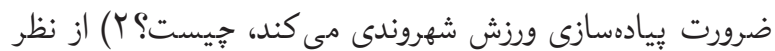
شما، براى اين كه مشاركت شهروندان در كلانشهرها در فعاليتهاى وززشى بيشتر شود جه بايد كرد؟؟) آيا از طريق حمل و نقل فعال مىتوان روى ورزش شهروندى تأثيرگذار بود؟ يك الكوى نمونه از كلان شهرهايى كه در خارج از كشور در حوزه ورزش شهروندى موفق عمل كردهاند مثال بزنيد؟....) يس از انجام هر مصاحبه، نسبت به ييادهسازى مصاحبه اقدام شده است. يثوهش در مرحله كيفى داراى مقبوليت، انتقال يذيرى، تأييد 


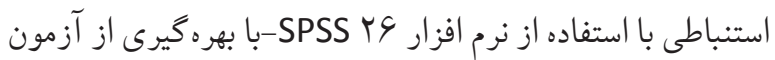
دبليو كندال و محاسبه ميانگين، انحر اف معيار و ميانگين رتبهاى انجام گرفت. با توجه به ضر يب هماهنكى كندال، يس از رسيدن به

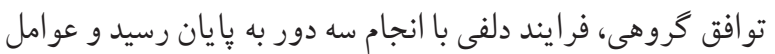

مر حله نيز همانند مرحله قبل بوده است كه برابر جدول ( ) مشروح

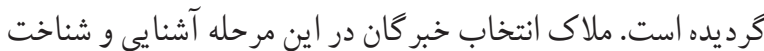
مبانى نظرى و تخصص در حوزه ورزش شهروندى بوده است.

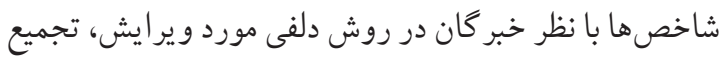
و يا حذف قرار گرفت و در نهايت تجزيه و تحليل اين مرحله با آمار جدول ا. ويثَى هاى انتخاب خبر گَان در مرحله مصاحبه دلفى

\begin{tabular}{|c|c|c|c|c|c|c|}
\hline \multirow{2}{*}{ 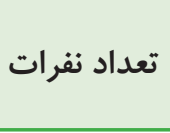 } & \multicolumn{5}{|c|}{ شهر فعاليت خبر كان } & \multirow{2}{*}{ ملاكى انتخاب } \\
\hline & تبريز & 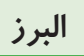 & 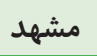 & اصفهان & 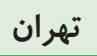 & \\
\hline ا ت انفر & & & & & 1 & مدير كل ورزش و جوانان استانها \\
\hline ك أنفر & 1 & 1 & r & & r & مديران سازمان ورزش شهردارى استانها \\
\hline 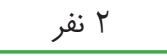 & & & & 1 & 1 & مسئول ورزش همعانى استانها \\
\hline 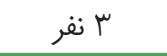 & & & & 1 & r & كارشناس مراكز ورزشى سازمان ورزش استانها \\
\hline 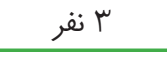 & & & 1 & 1 & 1 & فعالان ورزش شهروندى استانها \\
\hline 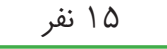 & & & & & & جمع \\
\hline
\end{tabular}

يافته ها

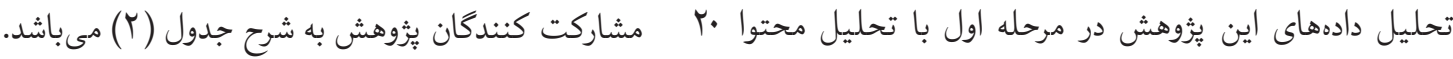

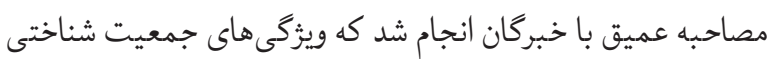
جدول r. ويثَى متغير هاى جمعيت شناختى مرحله كيفى

\begin{tabular}{|c|c|c|c|c|c|}
\hline \multicolumn{2}{|c|}{ حوزه فعاليت } & \multirow{2}{*}{ رشته تحصيلى } & \multirow{2}{*}{ تحصيلات } & \multirow{2}{*}{ 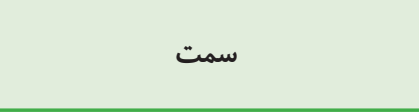 } & \multirow{2}{*}{ رديف } \\
\hline 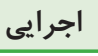 & دانشخاهى & & & & \\
\hline * & & فقه و حقوق & كارشناس ارشد & مسئول ورزش شهروندى مشهد & مصاحبه كننده 1 \\
\hline * & & 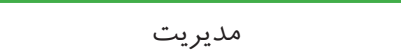 & كارشناس ارشد & مسئول ورزش شهروندى مشهد & مصاحبه كنده r r \\
\hline * & * & مديريت ورزشى & 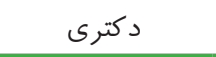 & مدير ورزش دانشكاهى اصفهان & مصاحبه كنده r \\
\hline * & & مديريت آموزشى & 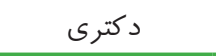 & مسئول ورزش شهروندى اصفهان & 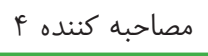 \\
\hline * & & مديريت ورزشى & 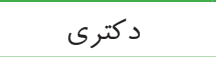 & مسئول ورزش شهروندى كرمان & مصاحبه كننده ه \\
\hline * & & كامِيوتر & كاردانى & كارشناس ورزش شهروندى كرج & مصاحبه كننده \\
\hline \multirow[t]{2}{*}{ * } & * & مديريت ورزشى & دانشجوى دكترى & كارشناس ورزش شهروندى اصفهان & V مصاحبه كنده V \\
\hline & * & مديريت و برنامهريزى امور ورزشى & 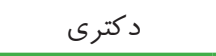 & هيات علمى دانشكاه شيراز & مصاحبه كننده 1 \\
\hline * & & مديريت راهبردى در ورزش & دانشجوى دكترى & مسئول ورزش شهروندى تهران & مصاحبه كننده 9 \\
\hline * & & مديريت ورزشى & 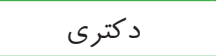 & معاون ورزشى تفريحى اصفهان & مصاحبه كننده · 1 \\
\hline * & & مديريت ورزشى & كارشناس ارشد & مسئول ورزش شهروندى تبريز & مصاحبه كننده 11 \\
\hline * & & 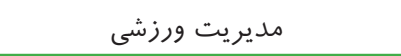 & دانشجوى دكترى & مدير ورزش و تفريحات سالم زاهدان & مصاحبه كنتده r| \\
\hline * & * & مديريت ورزشى & د دكترى & مدير ورزش اهواز & مصاحبه كننده سا \\
\hline
\end{tabular}




\begin{tabular}{|c|c|c|c|c|c|}
\hline 米 & & حر كات اصلاحى & دانشجوى دكترى & مسئول ورزش همعانى كرمان & مصاحبه كننده If \\
\hline * & * & مديريت ورزشى & 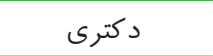 & هيات علمى دانشگاه تهران & مصاحبه كننده 10 \\
\hline * & & مديريت ورزشى & دانشجوى دكترى & مسئول ورزش شهروندى اروميه & مصاحبه كننده 19 \\
\hline * & & مديريت ورزشى & دانشجوى دكترى & كارشناس ورزش شهروندى تهران & مصاحبه كننده IV \\
\hline * & * & تاريخ & 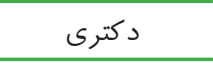 & مسئول ورزش شهروندى قم & مصاحبه كننده 11 1 \\
\hline * & & مديريت ورزشى & 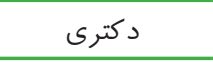 & مسئول ورزش شهروندى اصفهان & مصاحبه كننده 19 \\
\hline * & * & مديريت ورزشى & 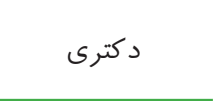 & كارمند سازمار دانشعاه تربيت مدرزش تهران & مصاحبه كننده ·r \\
\hline
\end{tabular}

ابتدا كد گذارى باز تمامى مصاحبههاى ضبط شده، انجام گرفت شاخصهاى استخر اج شده در مصاحبه دلفى مطرح گرديدند و پس كه تعداد ا • ب كد باز از مصاحبه هاى صورت گرفته استخراج گرديد از سه دور، مصاحبه هاى دلفى در راستاى شناسايى شاخصهاى و سيس با بهره گيرى از مرور مطالعات نظام مند كدها تجميع و در D山 تأثير گذار ورزش شهروندى سلامت محور كلان شهرهاى ايران، به شاخص برابر جدول (ب) دسته بندى گرديد. در مرحله دوم يثوهش، توافق و اجماع گروهى رسيد.

جدول س. كدهاى استخراجشده از مصاحبه ها

\begin{tabular}{|c|c|c|c|}
\hline نمونهاى از مصاحبههاى مشار كت كنند كان & كد ثانويه & 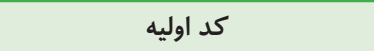 & رديف \\
\hline \multirow{6}{*}{ 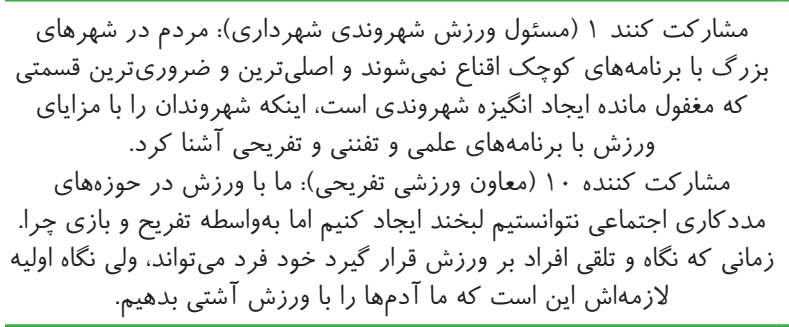 } & \multirow{6}{*}{ 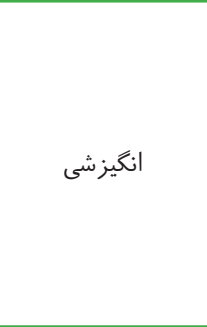 } & 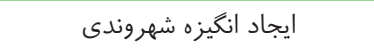 & \multirow{6}{*}{1} \\
\hline & & آشتى دادن آدمها با ورزش & \\
\hline & & تهييج مردم به سمت ورزش & \\
\hline & & ترغيب انخيزه حضور & \\
\hline & & آيتمهاى تشويقى & \\
\hline & & علاقهمند كردن شهروندان به ورزش & \\
\hline \multirow{6}{*}{ 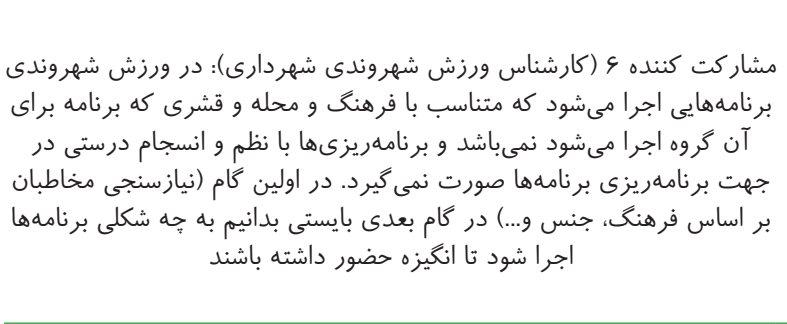 } & \multirow{6}{*}{ نيازسنجى مشار كت } & شناخت نيازمندى ورزش & \multirow{6}{*}{ r } \\
\hline & & نيازسنجى & \\
\hline & & نيازسنجى نيازهاى بدنى كودكان & \\
\hline & & نيازهاى حوزه ورزش شهروندى & \\
\hline & & شناسايى نيازها و خواستههاى مردم & \\
\hline & & بررسى نيازهاى ورزشى افراد جامعه & \\
\hline \multirow{2}{*}{ 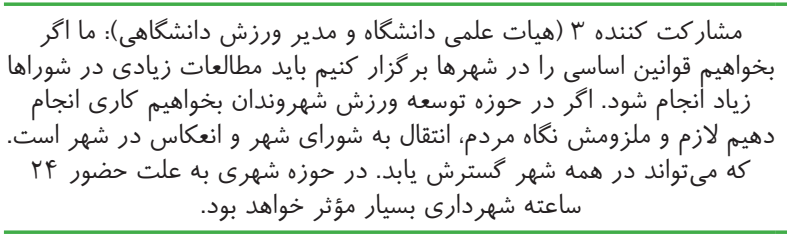 } & \multirow[b]{2}{*}{ شناسايى ظرفيت هاى } & انجام مطالعات گسترده & \multirow[b]{2}{*}{ r } \\
\hline & & شناسايى ظرفيت هاى هر منطقه & \\
\hline \multirow{7}{*}{ 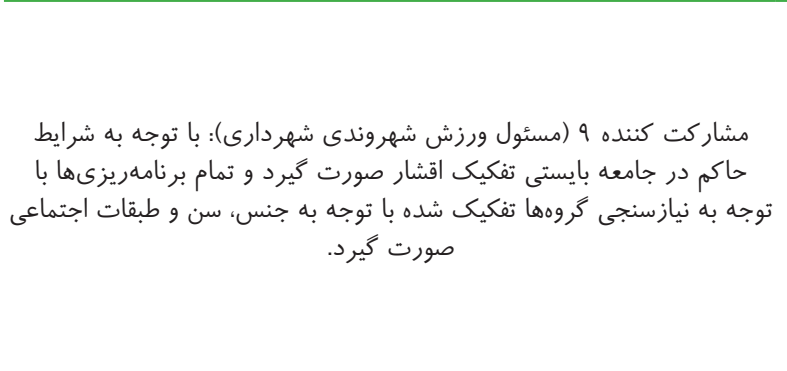 } & \multirow{7}{*}{ 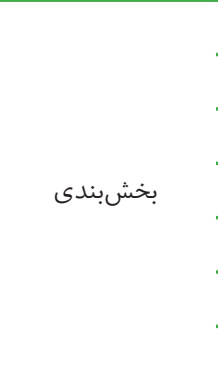 } & مقولهبندى مخاطبان & \multirow{7}{*}{ r } \\
\hline & & شناسايى گروه مخاطبان & \\
\hline & & مقولهبندى مجموعههاى فعال & \\
\hline & & مقولهبندى توان مالى & \\
\hline & & دستهبندى گروههاى سنى & \\
\hline & & گروهبندى فعاليتهاى ورزشى & \\
\hline & & تفكيك اقشار & \\
\hline
\end{tabular}


مشاركت كنند ا (مسئول ورزش شهروندى شهردارى): ما نياز به تغيير ساختار

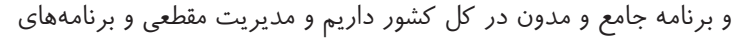

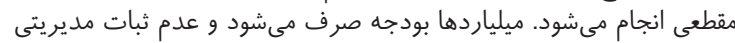

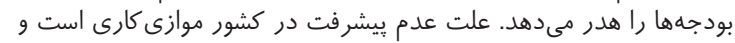

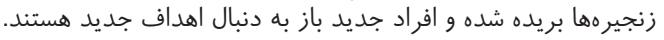

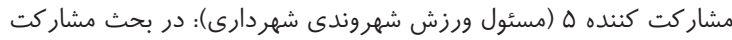

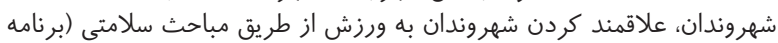

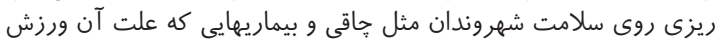

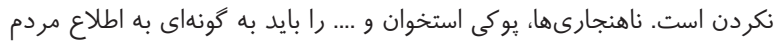

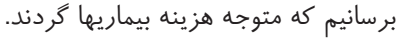

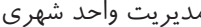

تمركز مديريت شهرى

مشار كت مديران

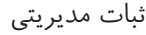

برنامهريزى مدون

برنامه جامع و مدون

جهت دادن به برنامهها

برنامهريزى بلندمدت

برنامهريزى

برنامهريزى كوتاهمدت برني

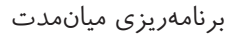

ارائه برنامههاى متنوع

ارائه برنامه از سوى دولت

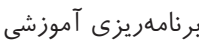

طلاعرسانى تخصصى به مخاطبان

اطلاعرسانى به خانوادهها

مشاركت كننده ||$($ (مسئول ورزش شهروندى شهردارى): ما در بحث

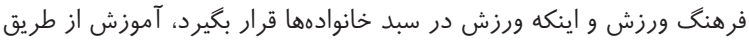

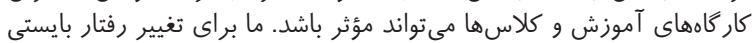

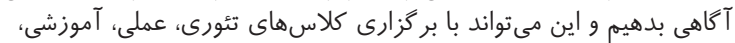

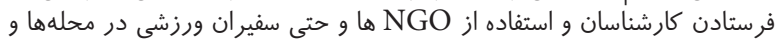

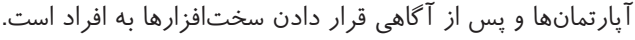

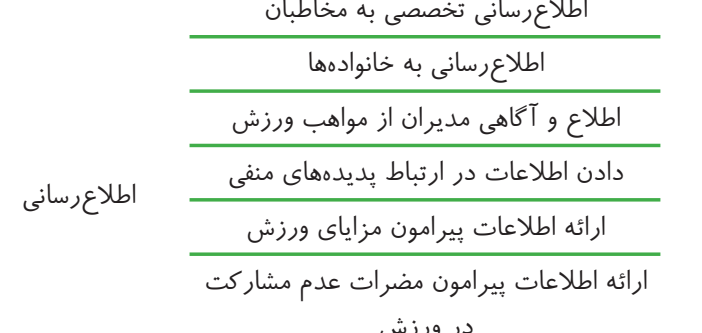

ב إن ورزش

افزايش اطلاعات مردم در زمينه ورزش

دادن آكاهى به مردم

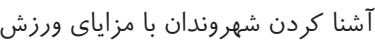

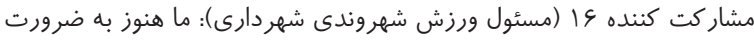

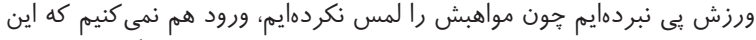

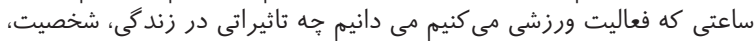

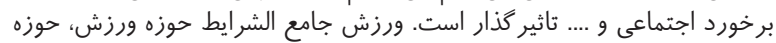
دييلماتيك (وزارت امور خارجه)، بايد تفكرات مختلف است همان الثرام شوند.

آكاهى دادن

آكاهسازى شهروندان از فضاهاى بازى كود كان

\begin{tabular}{|c|}
\hline آكاهى از مواهب ورزش \\
\hline آكاهسازى كارشناسان \\
\hline آكاهى سازى مديران نسبت بلهضرورت ورزش \\
\hline آكاهى دادن \\
\hline آكاهى دادن نسبت به نيازهاى جسمى افراد \\
\hline
\end{tabular}

استفاده از افراد بانكيزه در توسعه و يِشرفت ورزش

مشاركت كننده • r (مدير عامل سازمان ورزش): ما در كشور شايستهسالارى

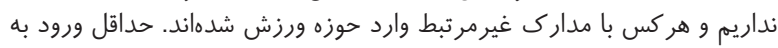

$$
\text { اين حوزه مديريت داشتن است. }
$$

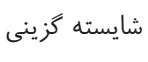

وجود مربيان براى استفاده صحيح از دستكاههاى

ورزشى

استفاده از افراد توانمند در بحث مديريت

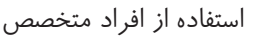

استفاده از كارشناسان با دانش و با تجربه

بل الموز بودن كارشناسان 
مشاركت كننده 4 (كارشناس ورزش شهروندى شهردارى): در ورزش شهر شهروند

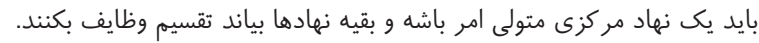

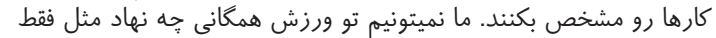

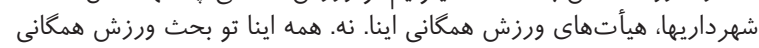

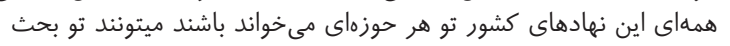

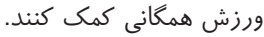

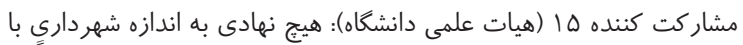

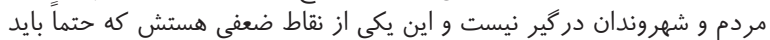

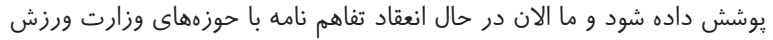

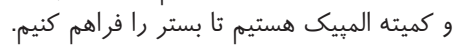

\begin{tabular}{|c|c|c|}
\hline \multirow{5}{*}{ هماهنگى } & همخر ايى مسئولين & \multirow{5}{*}{1 . } \\
\hline & تقسيم كار بين سازمانها و نهادهاى مختلف & \\
\hline & افزايش هماهنكى بين اركانها & \\
\hline & همكرايى اجتماعى و موجى & \\
\hline & تقسيم وظايف بين ارگانها & \\
\hline \multirow{4}{*}{ يكيارجهسازى } & مشخص شدن ساختار ورزش همخانى & \multirow{4}{*}{11} \\
\hline & همت بالا در نهادها & \\
\hline & تدوين تفاهمنامه & \\
\hline & مشخص كردن هدف & \\
\hline \multirow{6}{*}{ استفاده از ظرفيتهاي } & استفاده از ظرفيت سازمانهاى مردمنهاد & \multirow{6}{*}{ Ir } \\
\hline & استفاده از مشهورين و قهرمانان ورزشى & \\
\hline & استفاده از ظرفيت خانوادهها & \\
\hline & استفاده از ظر فيت اماكن مختلف & \\
\hline & استفاده از بازىهاى بومى محلى & \\
\hline & ظرفيت انسانى & \\
\hline
\end{tabular}

مشار كت كننده 9 (كارشناس ورزش شهروندى شهردارى): بحث تبليغات

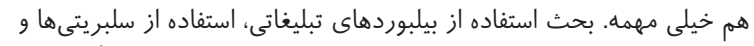

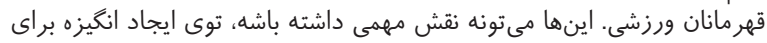
ورزش كردن مردم داشته باشه.

$$
\begin{aligned}
& \text { سرمايه گذارى در ورزش همغانى }
\end{aligned}
$$

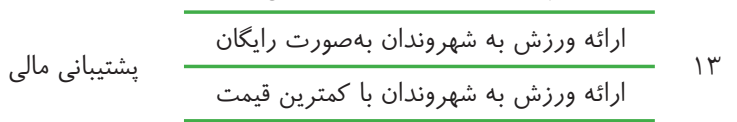

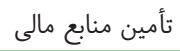

$$
\begin{aligned}
& \text { كار كردن بر روى باور مردم نسبت به ورزش منابع مالى }
\end{aligned}
$$

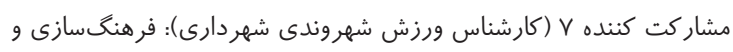

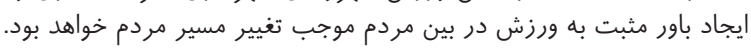

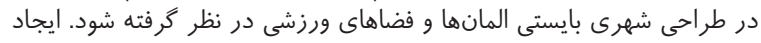

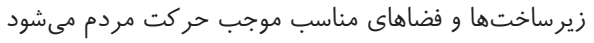

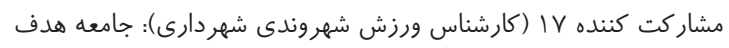

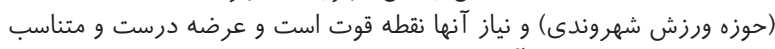

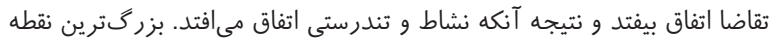

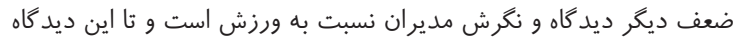

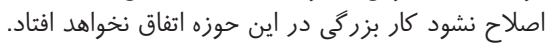

مشار كت كننده 9 (مسئول ورزش همكانى شهردارى): حوزه دولتى بى انخيزه و

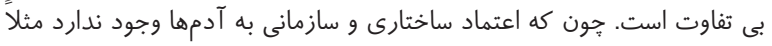

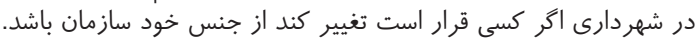

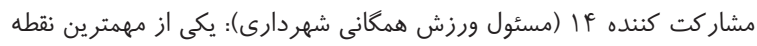

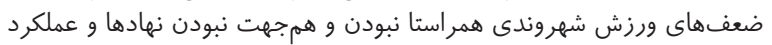
جزيراى آنهاست.

\begin{tabular}{|c|c|}
\hline \multirow{4}{*}{ د - إك ورزش } & كار كردن بر روى باور مردم نسبت به ورزش \\
\hline & بينش مثبت تصميم گيرندگان در ارتباط با ورزش \\
\hline & ديدكاه مثبت شهردار نسبت به ورزش \\
\hline & ايجاد باور مثبت به ورزش \\
\hline \multirow{2}{*}{ تغيير نكرش } & تغيير نغرش افراد \\
\hline & تغيير نگرش مديران شهردارى \\
\hline
\end{tabular}

دولتى فكر كردن

دخالت سياست در مديريت شهرى

تصميم گيرى خودسرانه نهادها

نبود هماهنكى در فعاليتها

عدم هماهنكى بين اركانها

موانع ساختارى

\begin{tabular}{|c|}
\hline موازى كارى ها \\
\hline همراستا نبودن \\
\hline تعدد متوليان ورزشى \\
\hline جزيرهاى عمل كردن \\
\hline متفاوت بودن الكَوها \\
\hline نبودن مديريت جامع \\
\hline
\end{tabular}




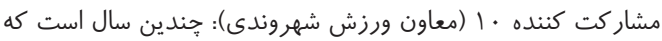

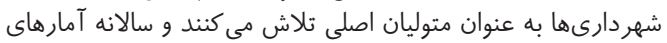

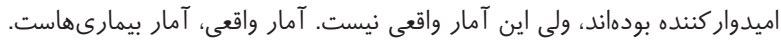

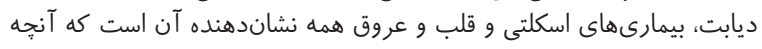

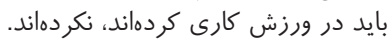

\begin{tabular}{|c|c|c|}
\hline \multirow{4}{*}{ كمبود دانش } & نداشتن آمار & \multirow{4}{*}{ IV } \\
\hline & نداشتن تعريف درست از اوقات فراغت & \\
\hline & نشناختن نقاط ضعف & \\
\hline & عدم شناخت مأموريت & \\
\hline & نداشتن برنامه & \\
\hline
\end{tabular}

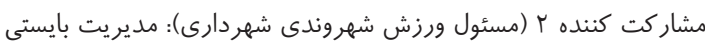

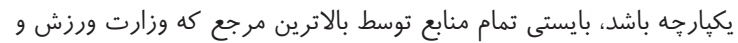

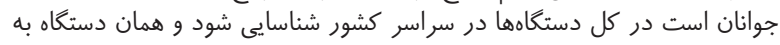
عنوان مديريت كلان به دنبال راهبردها دها باشد.

مشاركت كننده 19 (مسئول ورزش شهروندى شهردارى): ورزش براى براى مديران

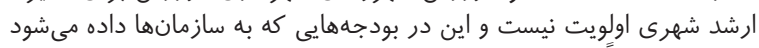

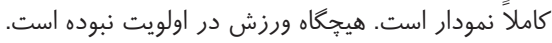

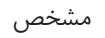

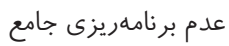

11

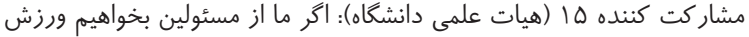

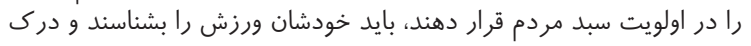

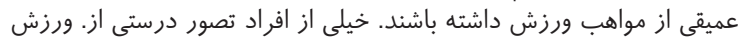

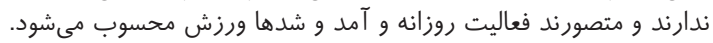

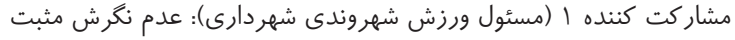

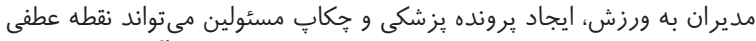

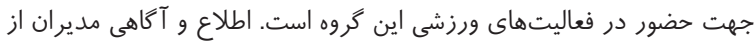

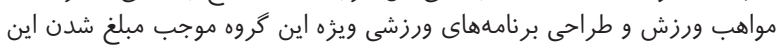
كروه براى جامعه است ورن اين
هزينه نكردن در ورزش بـ بـن

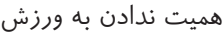

موانع مالى

اولويت نبودن ورزش نزد مديران ارشد شهرى بهر

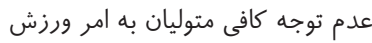

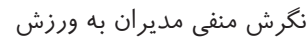

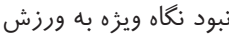

موانع شناختى

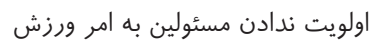

نير داختن به ضر رهاى ورزش

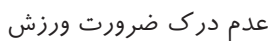

عدم آكاهى مردم نسبت به ورزش

مشخص نبودن اهميت ارزش فعاليت بدنى در مردم

جامعه

قوانين دست و پاگير

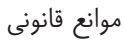

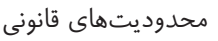

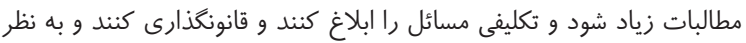

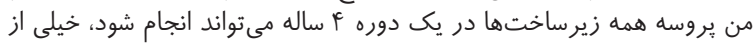

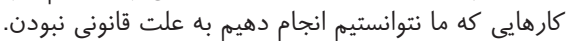

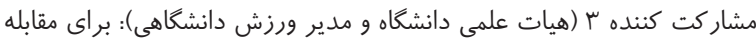

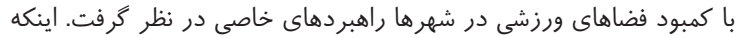

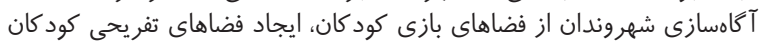

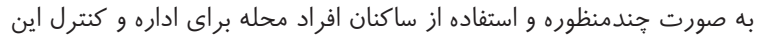

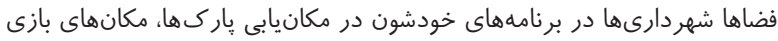

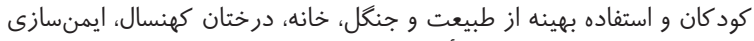

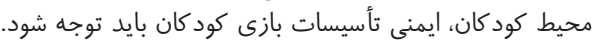

\begin{tabular}{|c|c|c|c|}
\hline 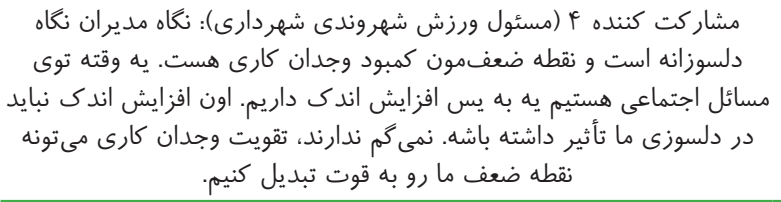 & موانع فردى & كمبود وجدان كارى & $r$ \\
\hline 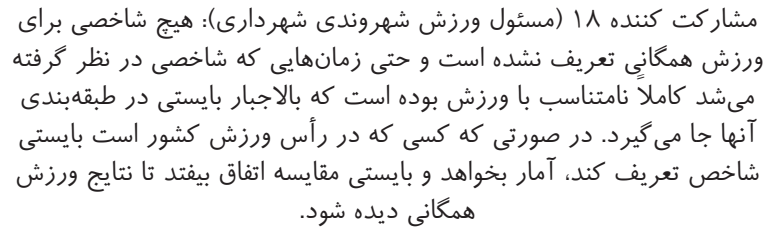 & موانع اطلاعاتى & نبود پايخاه دادههاى يِرامون اثرات ورزش & rF \\
\hline
\end{tabular}




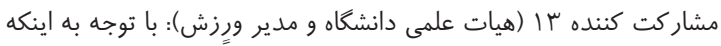

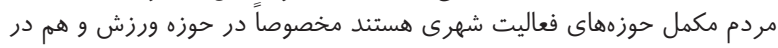

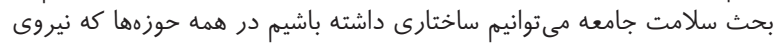

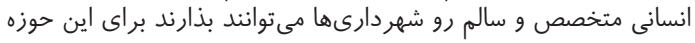

$$
\begin{aligned}
& \text { عدم توانمندى مديران در كار مشار كتى } \\
& \text { ro } \\
& \text { سوء مديريت } \\
& \text { نبود افراد متخصص }
\end{aligned}
$$

مشار كت كننده V (مسئول ورزش شهروندى شهر شهردارى): مردم در شهر هاى

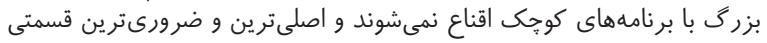

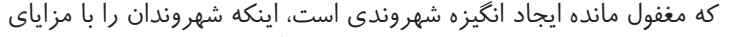

\begin{tabular}{|c|c|}
\hline \multirow{5}{*}{ 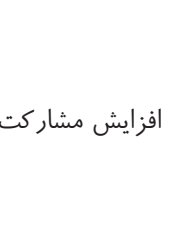 } & انخيزه بالاى مردم در انجام ورزش \\
\hline & علاقه مردم به ورزش همكانى \\
\hline & افراد بيشتر خواهان ورزش كردن هستند \\
\hline & عادت مردم به انجام ورزش \\
\hline & حضور حداكثرى مردم \\
\hline
\end{tabular}

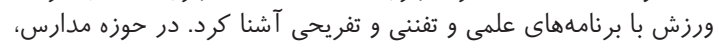

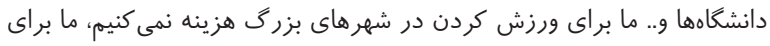
نمردن هزينه مى كنيم.

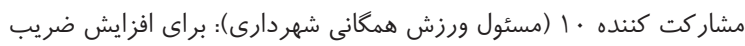

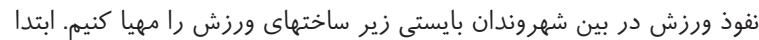
ورزشكاهها و اماكن ورزش هم در دسترس و هم ارزان ارائه خدمات داشئ داشته باشند.

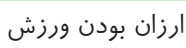

جذابيتهاى ورزش جذابيت ورزش بردان rV

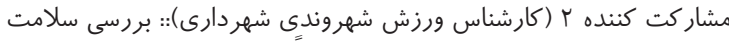

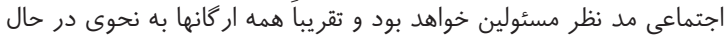

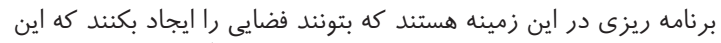

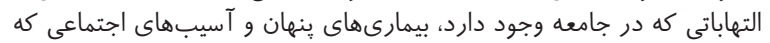

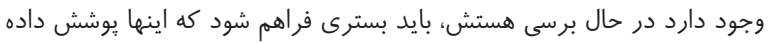

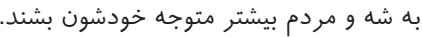

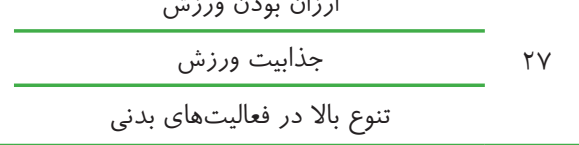

سلامت اجتماعى اجتى

افزايش نشاط و بهبود سلامتى و شادابى بيشتر روحيه

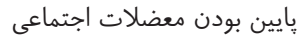

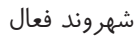

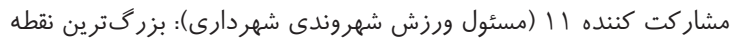

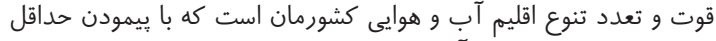

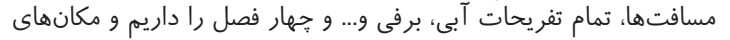

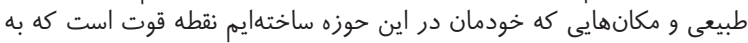

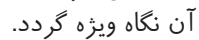

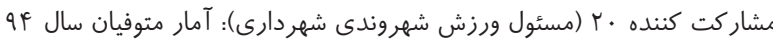

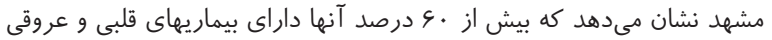

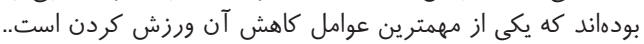

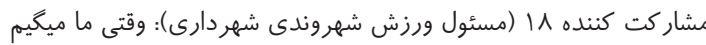

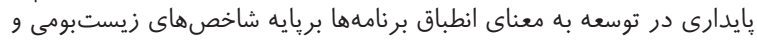

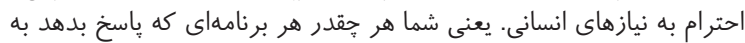

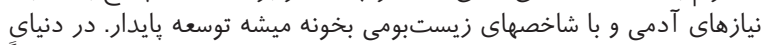

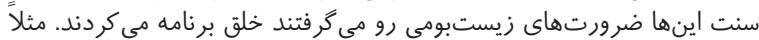

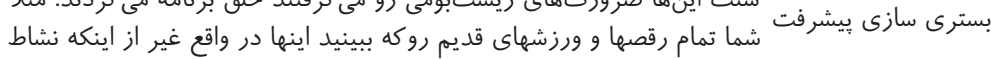

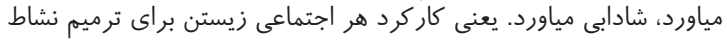

\begin{tabular}{|c|c|c|}
\hline \multirow{3}{*}{ جذابيت هاى محيطى } & تنوع اقليم آب و هوايى & \multirow{3}{*}{ rq } \\
\hline & فضاهاى سبز & \\
\hline & وجود فضاهاى طبيعى در كشور & \\
\hline \multirow{2}{*}{ حفظ سلامتى } & كاهش بيمارهاى قلبى و عروقى & \multirow{2}{*}{ r. } \\
\hline & كاهش نرخ استفاده از امكانات درمانى & \\
\hline & مسير توسعه كشور & \\
\hline & توسعه عمومى جامعه & \\
\hline
\end{tabular}

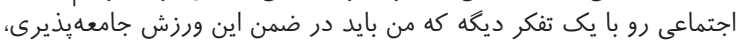

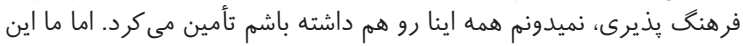

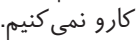

توسعه اقتصادى

مشار كت كننده ץ (هيات علمى دانشگاه و مدير ورزش دانشكاهى): تعبيه

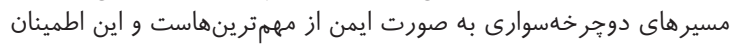

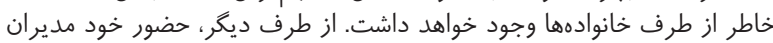

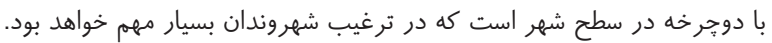

حملونقل فعال

سيستم حملونقل مناسب

سيستم حملونقل عمومى حملونس مناسب اتصال مسيرهاى دوجر خهسوارى به حملونقل

عمومى

حمل و نظم دقيق و منظم ميسر

ايجاد حملونقل فعال 


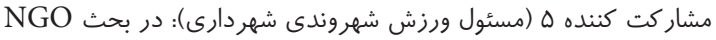

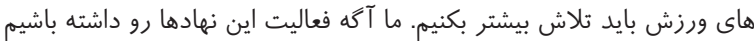

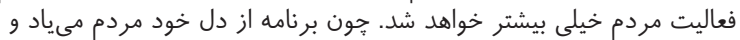

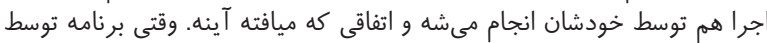

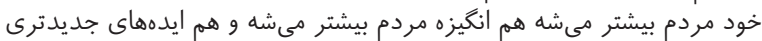

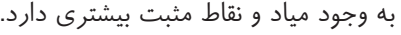

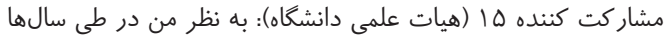

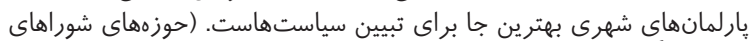

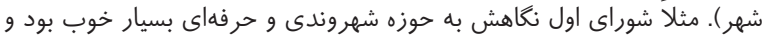

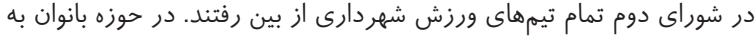

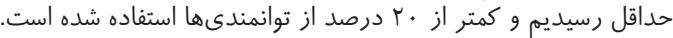

\begin{tabular}{|c|c|}
\hline & هيأت هاى ورزشى همكانى \\
\hline & اداره كل ورزش استانها \\
\hline & دانشگاهها \\
\hline & آموزشويرورش \\
\hline & رسانها \\
\hline & شهردارى ها \\
\hline \multirow{7}{*}{ ورزش شهاعه دهندههاى } & فدراسيون همخانى \\
\hline & 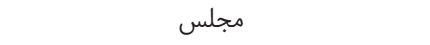 \\
\hline & نهادهاى خصوصى \\
\hline & 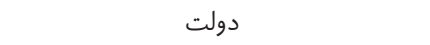 \\
\hline & معاونت فرهنكى مناطق و شوراهاى اجتماعى \\
\hline & يارلمانهاى شهرى \\
\hline & وزارت ورزش و جوانان \\
\hline
\end{tabular}

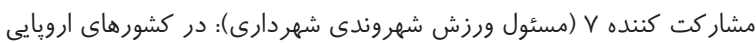

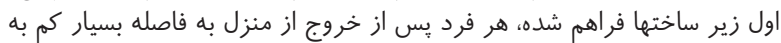

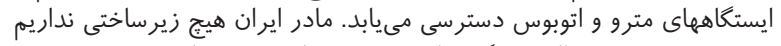
و به دنبال فرهنگ سازى هستيم و اين نشدنى است.

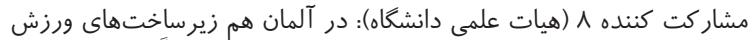

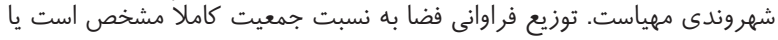

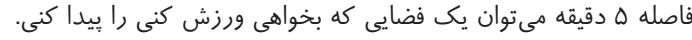

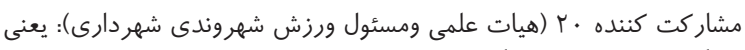

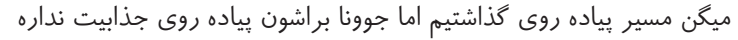

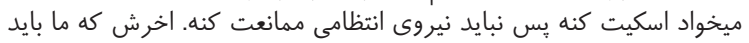

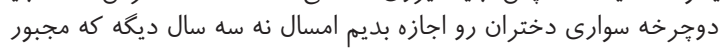
ميشيم.

\begin{tabular}{|c|c|c|}
\hline & در دسترس بودن اماكن ورزشى & \\
\hline 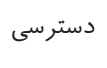 & دستر سي راحت & mp \\
\hline
\end{tabular}

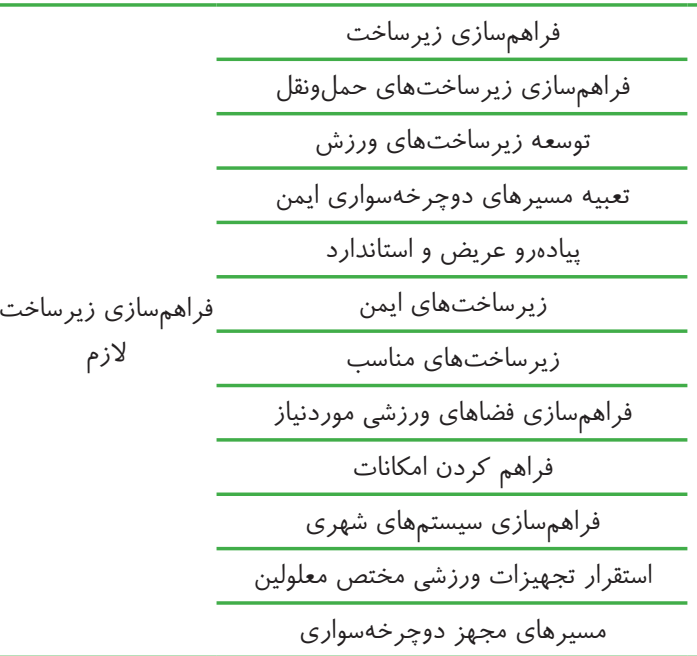

هماهنگى كندال و معنا دار نبودن با توجه به جدول (Y))، مصاحبه دلفى به دور بعدى راه يافت و در نهايت در دور سوم مصاحبه دلفى تعداد

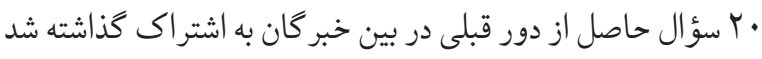

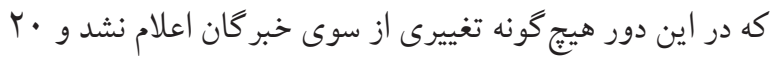
شاخص تأثير كذار به شرح جدول (ه) استخراج شد.

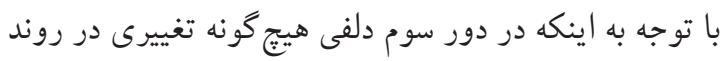

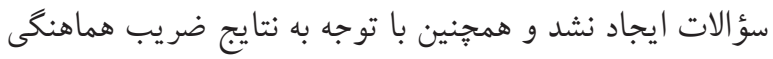

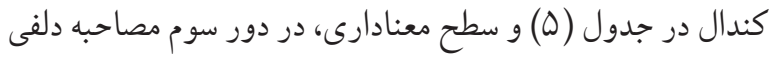

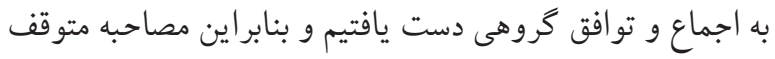

در دور اول مصاحبه دلفى تعداد هـ شاخص در قالب فهرستى

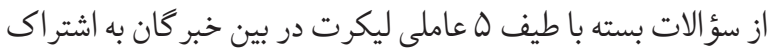

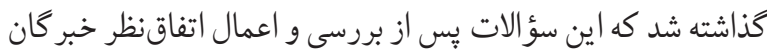

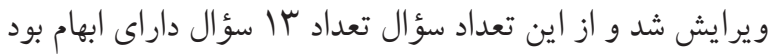
و قابليت هم يوشانى با سؤالات ديكر را داشت كه با نظر خبر گان و ير ايش گرديد. همجنين در دور دوم مصاحبه دلفى تعداد ب سؤ سوال حاصل از دور قبلى در بين خبر كان به اشتراك كذاشته شد كه با نظر مارد خبر كان تعداد ץ سؤال به علت هم يوشانى با ديخر سؤ الات تجميع كرديد و همجنين به علت وجود تغييرات و همجنين وجود ضريب ناجيز 
و شاخصهاى استخراج شده در اين دور به عنوان عوامل مؤثر همكانى شدن ورزش ايران تلقى گرديد. جدول ع. نتايج آزمون ضريب هماهنغى كندال دور دوم و سوم مصاحبه دلفى

\begin{tabular}{|c|c|c|c|c|}
\hline & حجم نمونه & درجه آزادى & سطح معنادارى & ضريب كندال \\
\hline دور دوم & 10 & rI & $\cdot / \cdot r \Lambda$ & $\cdot / 1 \cdot V$ \\
\hline دور سوم & 10 & 19 & $\cdot / \cdots$ & $\cdot 10 \cdot 9$ \\
\hline
\end{tabular}

جدول ه. شاخصهاى تأثير كَار ورزش شهروندى سلامتمحور كلانشهرهاى ايران

\begin{tabular}{|c|c|c|c|c|}
\hline 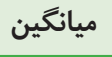 & انحراف معيار & ميانگين رتبهاى & 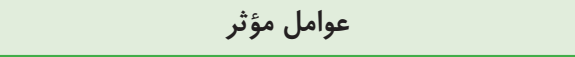 & رديف \\
\hline$r / 1$ & $\cdot /$ mo & $\Lambda / \& V$ & عوامل انخيزشى & 1 \\
\hline$r / \Lambda$ & $\cdot / 4 \mid$ & $10 / 1 V$ & 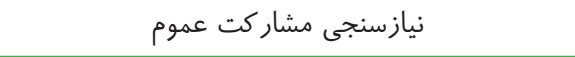 & r \\
\hline$r / \Lambda$ & . & $s / F V$ & شناسايى ظرفيت هاى دانشى & r \\
\hline$r / \Lambda$ & $\cdot /\left.\right|_{1}$ & $\Delta / 9 \vee$ & تمركز زدايى و بخشبندى اقشار جامعه و توان مالى & q \\
\hline$r / \Lambda$ & $\cdot / r \Delta$ & 10/А & ثبات مديريتى، مديريت واحد و متمركز شهرى & 0 \\
\hline$r / \Lambda$ & $\cdot / F_{1}$ & $10 / r$ & برناملريزى جامع و مدون & 4 \\
\hline$r / \Lambda$ & $\cdot /\left.\right|_{1}$ & $10 / 1 V$ & اطلاعرسانى، آكاهى بخشى و بهبود عوامل شناختى & $\checkmark$ \\
\hline$r / 1$ & $\cdot / \mu \Delta$ & $\Lambda / \& V$ & شايسته گزينى و اهتمام به تخصص گرايى & $\wedge$ \\
\hline r & $\cdot / r \Delta$ & $\wedge$ & هماهنگى و همافزايى كلان در كشور & 9 \\
\hline$r / l$ & $\cdot / \mu \Delta$ & N/צr & يكيارجهسازى و ايجاد ساختار كلان & 1 \\
\hline$r / \Lambda$ & $\cdot / 41$ & $10 / 18$ & يشتيبانى مالى & 11 \\
\hline$r / r$ & $\cdot|q|$ & $9 / \mu$. & ايجاد درى و نغرش صحيح & Ir \\
\hline$r / q$ & $\cdot / r \Delta$ & $s / \Lambda$ & وضع و تغيير قانونهاى حمايتى و توسعهاى & Ir \\
\hline$r / r$ & $\cdot / \mathbb{Q} \Delta$ & $9 / 94$ & حملونقل فعال شهرى & If \\
\hline$r / 1$ & $\cdot /$ ro & $\Lambda / S V$ & دسترسى آسان، ارزان و امن & 10 \\
\hline$r / \Lambda$ & $\cdot /$ / & IO/Ar & فر اهم بودن زيرساخت هاى لازم & 19 \\
\hline$r / r$ & $\cdot / \mathbb{Q} \Delta$ & $9 / 94$ & افزايش مشار كت عموم & IV \\
\hline$r / r$ & $\cdot / F \Delta$ & $9 / 94$ & بيان جذابيتهاى ورزش و محيط پِيرامونى & 11 \\
\hline r & $\cdot / r \Delta$ & $\wedge$ & بيان فوايد فرهنگى اجتماعى ورزش & 19 \\
\hline$r / 1$ & $\cdot / r \Delta$ & $\Lambda / S V$ & بيان فوايد سلامتى و تندرستى افراد جامعه & $r$. \\
\hline
\end{tabular}

يافتهاى يُوهش بيانكر آن است كه عوامل انگيزشى، نيازسنجى اقشار جامعه و توان مالى، ثبات مديريتى، مديريت واحد و متمركز

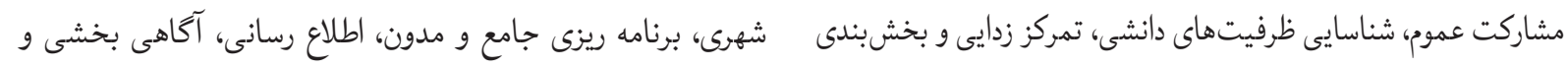


شهروندى، شناسايى نيازها و خواستهاى مردم، بررسى نيازهاى ورزشى افراد جامعه ميباشد، همسو است.

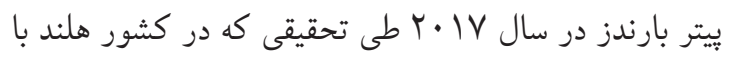
عنوان برنامه ملى، دانش و نو آورى در ورزش و فعاليت بدنى انجام

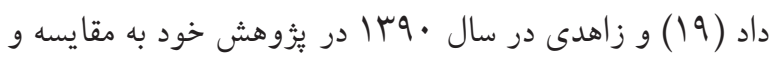
اولويت بندى استراتثىهاى توسعه ورزش همخانى در كشور از

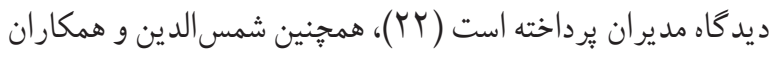

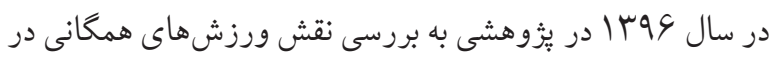

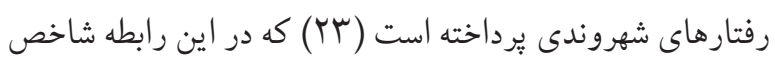

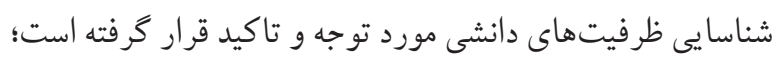

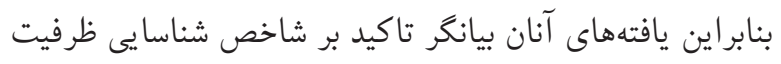

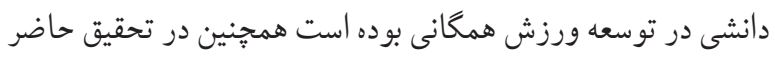
به انجام مطالعات گسترده و شناسايى ظرفيت هاى هر محله اشاره

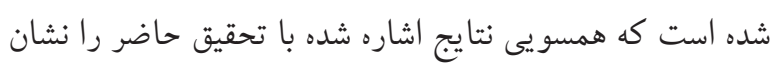

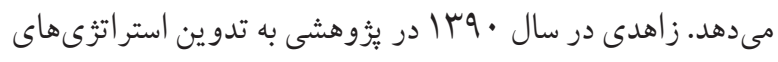

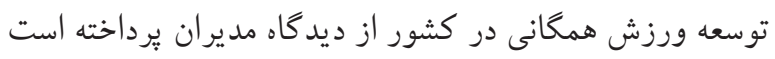

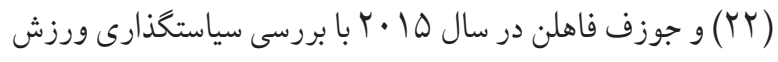

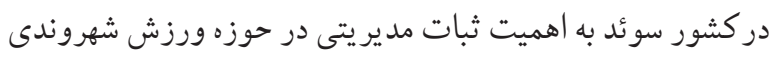

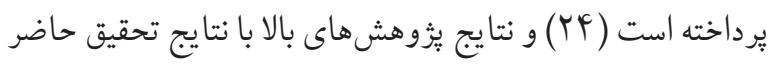

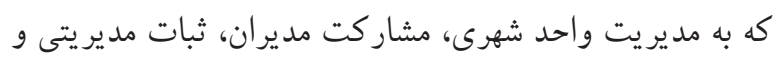
تمركز مديريت شهرى در اين بخش اشاره و تاكيد دارد همراستا

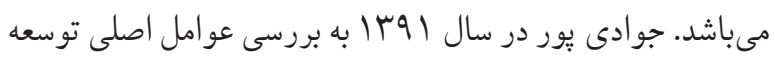
ورزش همخانى و وضعيت ورزش همخانى در كشورهاى استر اليا،

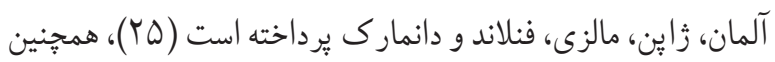

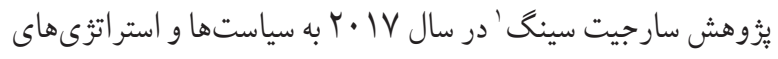
توسعه ورزش همخانى در كشور مالزى برداخته است (YV)، نتايج

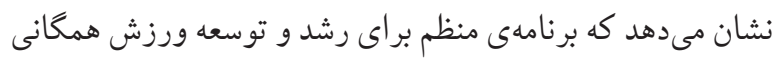

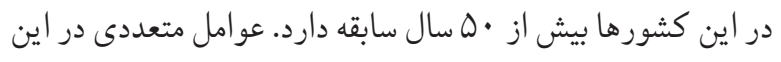
موفقيت نقش دارد كه قبل از هر جيز مى توان به برنامهريزى جامع و كلان در حوزه ورزش همكانى در اين حوزه اشاره كرد و نتايج
بو بهبود عوامل شناختى، شايسته گزينى و اهتمام به تخصص گرايى، هماهنكى و هم افزايى كلان دركشور، يكيارجه سازى و ايجاد ساختار كلان، يشتيبانى مالى، ايجاد درك و نحرش صحيح، وضع و تغيير قانونهاى حمايتى و توسعهاى، حملو نقل فعال شهرى، دسترسى

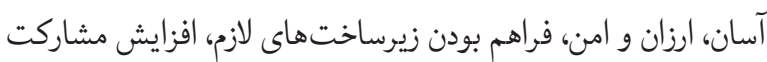

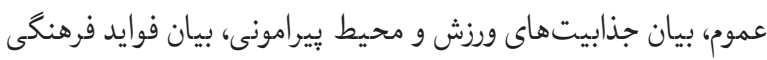

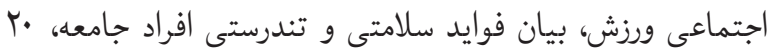
شاخص عوامل تاثيرگذار بر ورزش شهروندى كلان شهرهاى ايران محسوب مى گردند. در خصوص شاخص عوامل انكيزشى خالدى فرد و همكاران در حرد

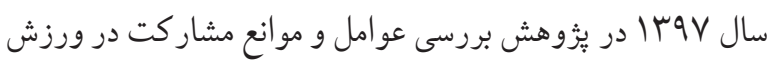

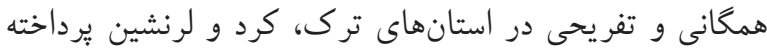

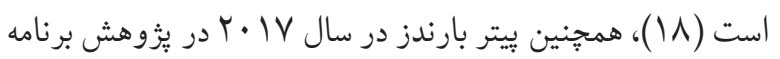

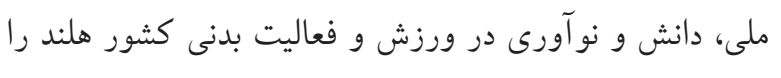
مورد بررسى قرار داده است (19) و در همين رابطه كارواليوويرا

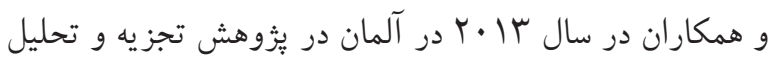

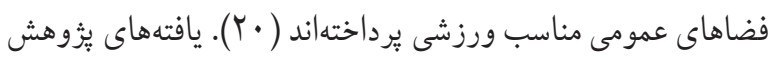

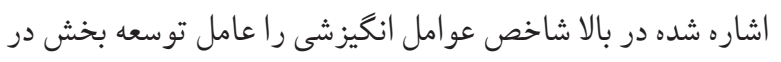

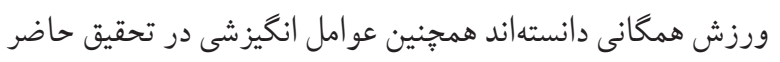

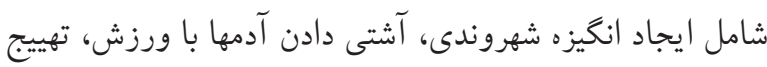

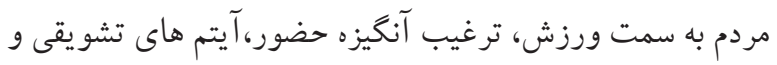

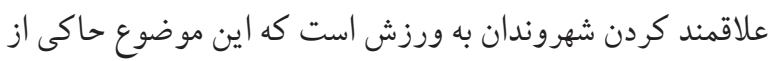
همسويى يافتهاى اين محققين با يافتهاى بثزوهش حاضر است.

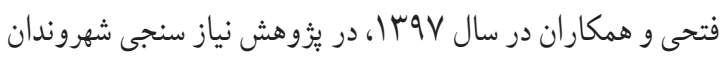
اروميهاى به ورزش همحانى به معنى دارى بين ميانگين نظر ات نمونه

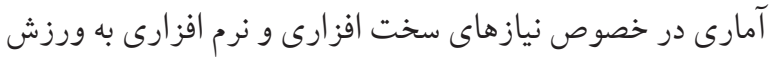

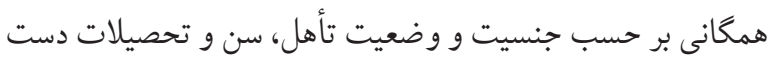

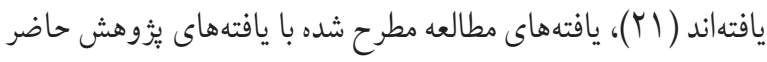
در خصوص استخراج عامل نيازسنجى مشاركت عموم در توسعه

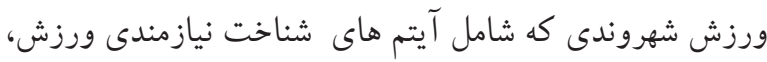

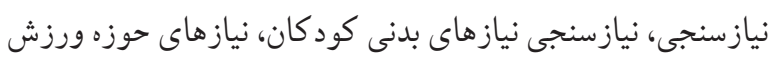


ايران يرداختند (TD) كه نتايج استخراجى اين تحقيق بيشنهاد ساختار

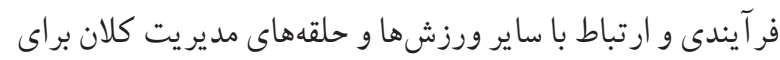

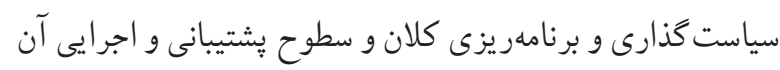
مىباشد. در يُوهش حاضر نيز به همخر ايى مسئولين، تقسيم كار بين سازمانها و نهادهاى مختلف، افزايش هماهنكى بين ار كانها،

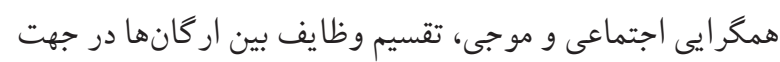
هماهنكى و هم افزايى تاكيد شده است كه نتايج با تحقيقات ارائه

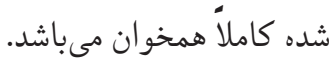

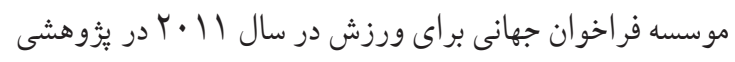

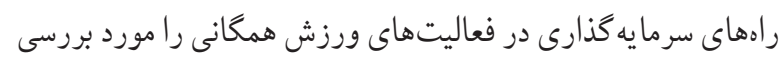

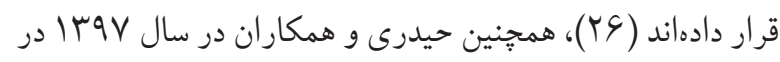

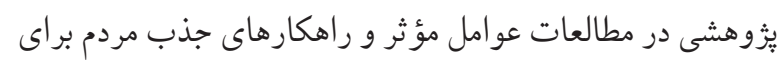

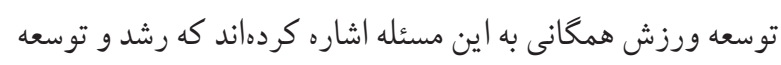

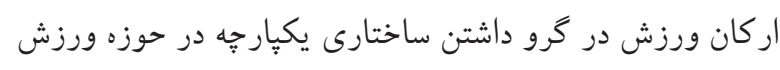

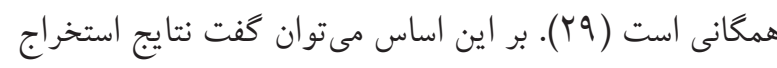
شده با خروجى تحقيق حاضر كه اشاره به همت بالا در نهادها، تدوين

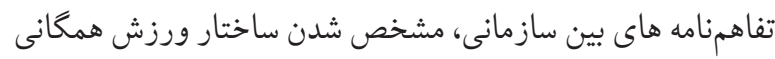

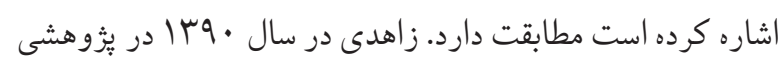
به تدوين استراتزىهاى توسعه ورزش همعانى در كشور از ديدگاه

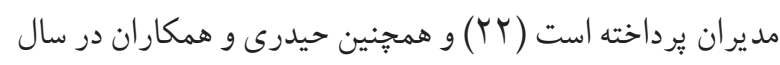

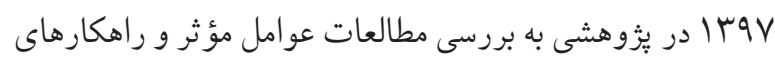

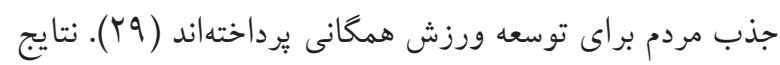

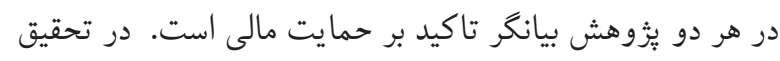

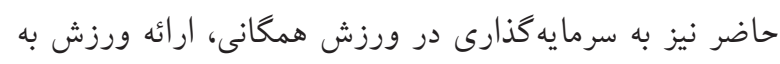
شهروندان بهصورت رايكان، ارائه ورزش به شهروندان با كمترين قيمت، تأمين منابع مالى اشاره شده است كه بيانكر همسو بيى با نتايج

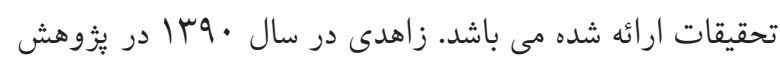
تدوين استراتزىهاى توسعه ورزش همگانى در كشور از ديدگاه

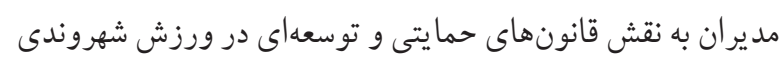

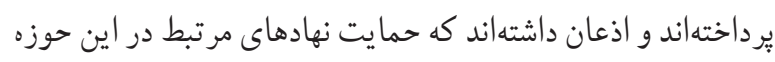

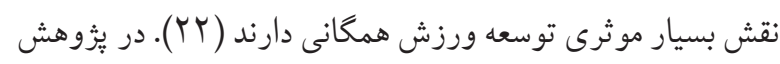

حاكى از آن است كه نتايج استخراج شده اين يُزوهش كه شامل

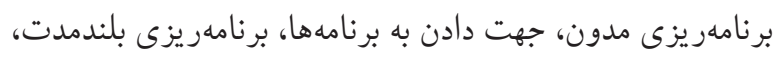

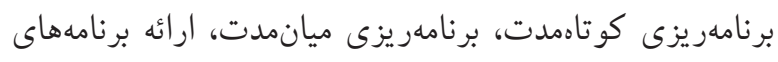

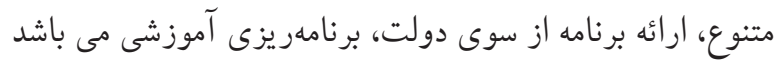
با نتايج تحقيقات ذكر شده مطابقت دارد. در خصوص شاخص اطلاعرسانى، آكاهى بخشى و بهبود

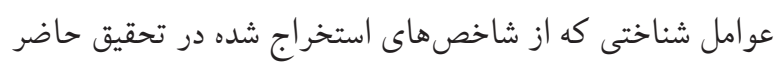

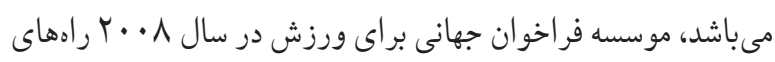

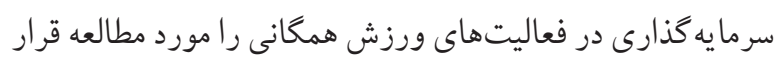

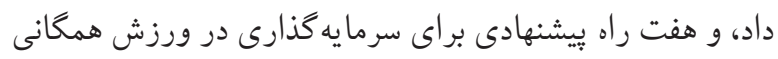

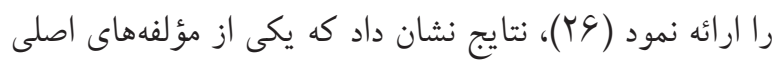

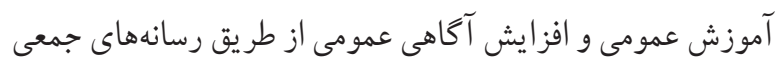

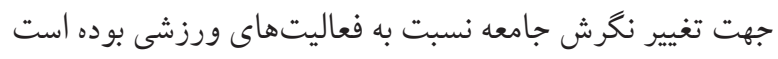

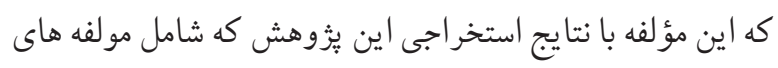

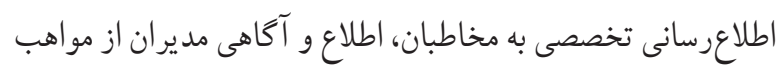

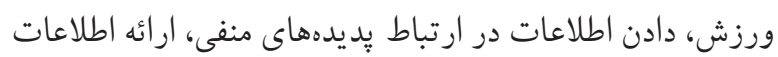
يير امون مضرات عدم مشاركت در ورزش، افزايش اطلاعات مردم

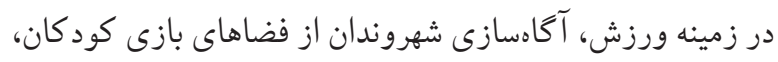

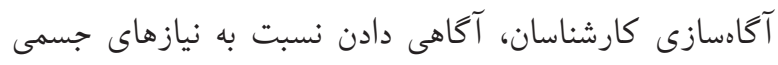

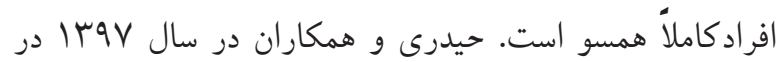
ثئوهشى به بررسى مطالعات عوامل مؤثر و راهكارهاى جذب

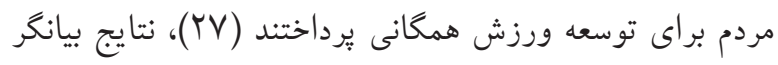

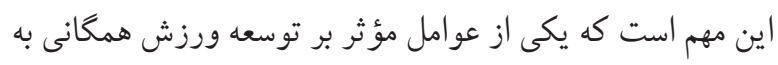

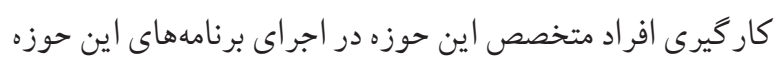
مى باشد.در تحقيق حاضر نيز به وجود مربيان براى استفاده صحيح

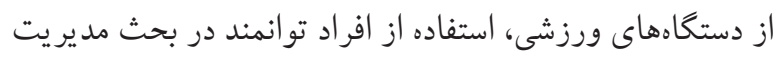

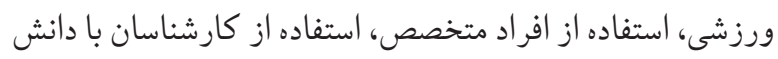

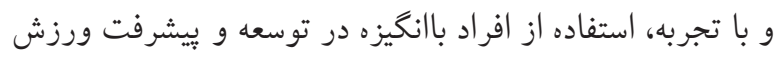

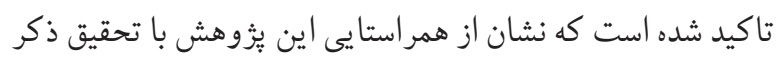

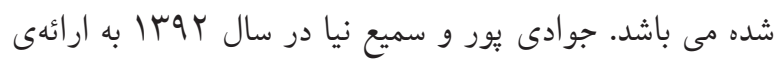

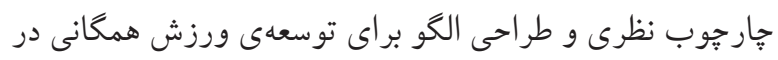


موثرتر ين شاخصها دست يافته است همسوست. يافتههاى تحقيق

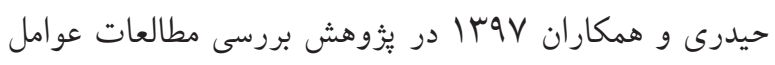
مؤثر و راهكارهاى جذب مردم براى توسعه ورزش همعانى (Y9) و همجنين ثُزوهش موسسه فراخوان جهانى براى ورزش در در سال

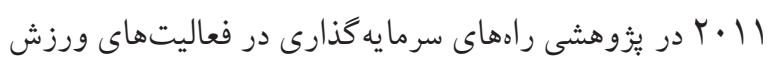

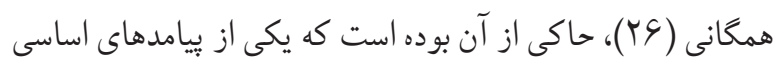

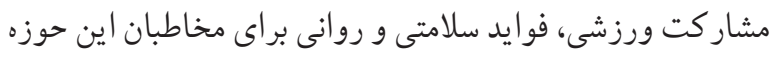

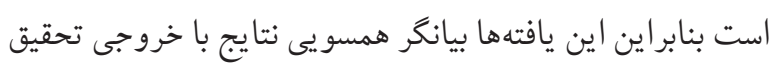

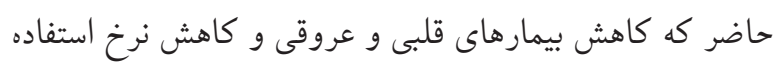

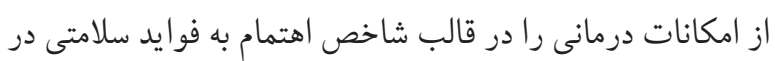

توسعه ورزش شهروندى عنوان نموده است كاملا همسوست.

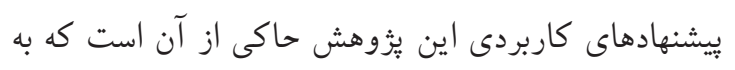

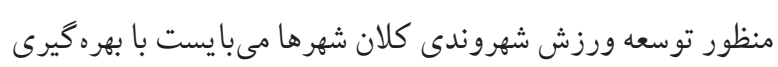
از نقشه راه و نظام جامع با تفكر راهبردى نسبت به توسعه بِايدار

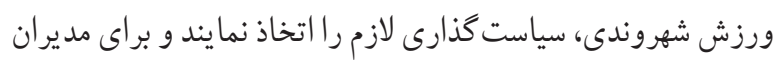
در تمامى سطوح قابليت اجر اي طرحهاى توسعهاى فراهم كردد و

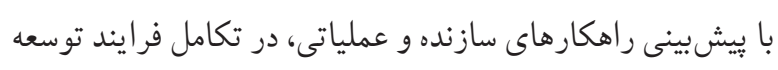

$$
\begin{aligned}
& \text { ورزش شهروندى اقدام نمايند. } \\
& \text { نتيجهة كيرى }
\end{aligned}
$$

با برنامهريزى و مديريت شهرى مطلوب با لحاظ كردن ·r عامل شناسايى شده، ورزش شهروندى كلان شهرهاى ايران به توسعه يايدار خواهد رسيد و سبب داشتن جامعهاى سالم و منجر به رشد شهروندان در ابعاد فرهنكى، اجتماعى، اقتصادى، سياسى و فناورى خواهد شد. توسعه ورزش شهروندى و افزايش مشاركت عموم مردم به ورزش،

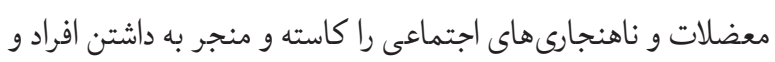

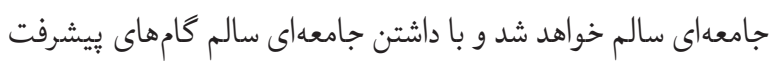

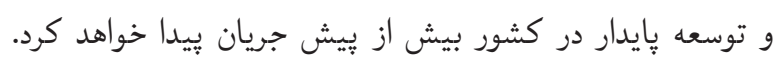

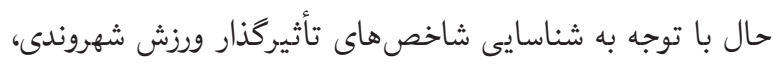

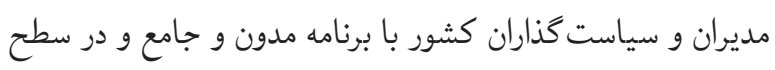

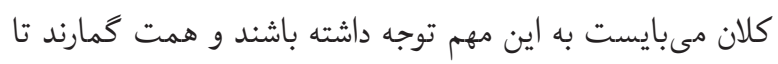

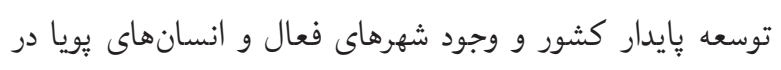

حاضر نيز شاخص تغيير و وضع قانون حمايتى، عوامل تاثير كذار

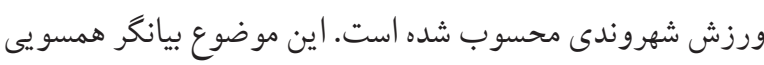

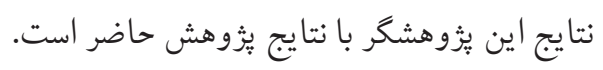

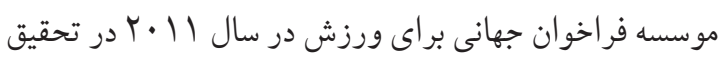

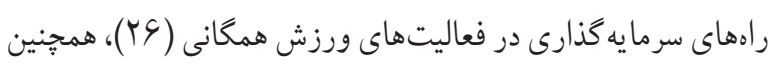

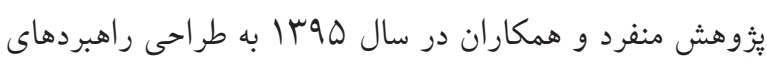

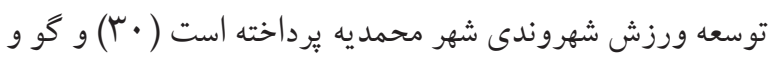

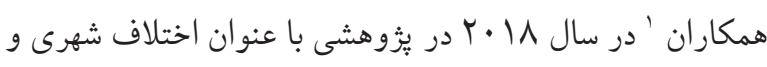
روستايى در رضايت از خدمات ورزشى عمومى برداختهاند ( آ؟).

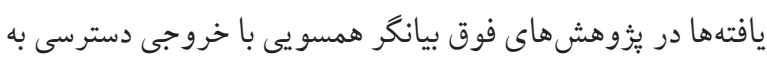

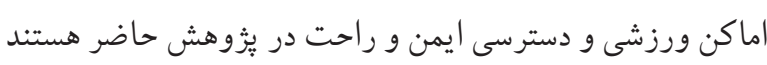

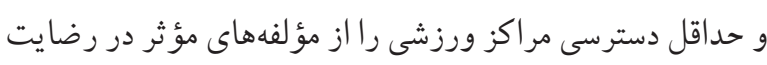

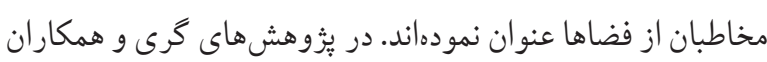

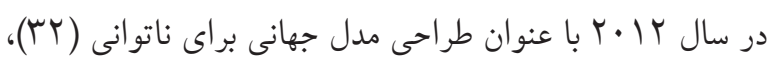

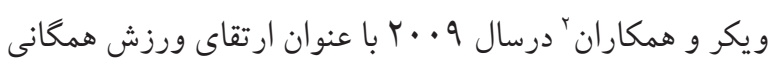

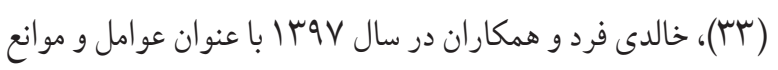
مشار كت در ورزش همكانى و تفريحى در استانهاى ترك، كرد و

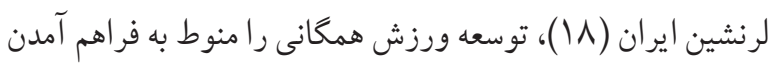

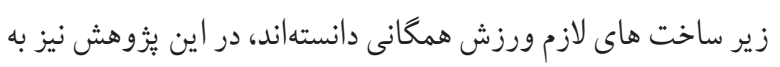

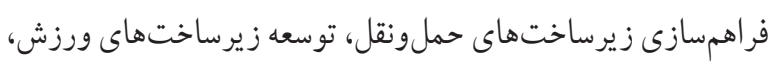

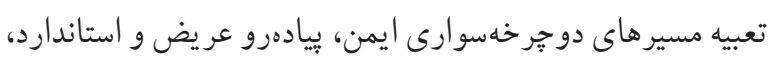
زير ساختهاى ايمن، فر اهم سازى فضاهاى ورزشى موردنياز، فر اهم

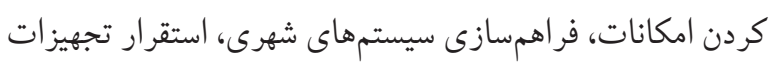

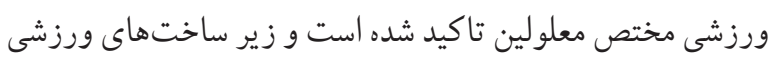
را در الكوى فعاليت ورزشى مؤثر مىداند كه اين نشاندهنده مطابقت نتايج با تحقيقات فوق مى باشد. نتايج تحقيق زاهدى در در سال

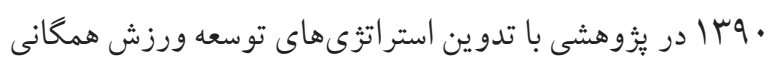

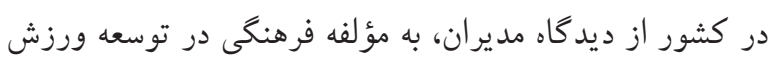
شهروندى اشاره داشته است (YT) بنابراين از اين حيث با نتايج تحقيق حاضر كه به شاخص اهتمام به فوايد فرهنكى به عنوان يكى از

1. Guo et al 2. Wicker,et al. 


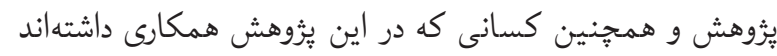
كمال تشكر و قدردانى مى نماييم.

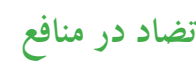
نويسندكان تصريح مى كنند كه هيج گونه تضاد منافعى در مطالعه حاضر وجود ندارد.

\section{Reference}

1. Khaw KT, Wareham N, Bingham S, Welch A, Luben R, Day $\mathrm{N}$. Combined impact of health behaviors and mortality in men and women: The EPIC-Norfolk prospective population study. PLoS Medicine. 2008; 8;5(1): e12. https://doi.org/10.1371/journal.pmed.0050012 PMid:18184033 PMCid:PMC2174962

2. Asefi A. Factors influencing the institutionalization of public sports in Iran: individual factors. Nashryeh Modiryate Varzeshi, 2018; 10(3): 415-434.

3. Syed Ameri MH, Qurbandi MA. Explaining strategies for attracting and increasing citizen participation in public and recreational program.Pajoheshhaie Modiryat Varzeshi Va Oloom Harkati. 2012; 2 (4): 23-34.

4. Huang WY, Wong $\mathrm{SH}$, Sit $\mathrm{CH}$, Wong MC, Sum RK, Wong SW, Jane JY. Results from the Hong Kong's 2018 report card on physical activity for children and youth. Journal of Exercise Science \& Fitness, 2019; 1: 17(1): 9-14. https://doi.org/10.1016/j.jesf.2018.10.003 PMid:30662509 PMCid:PMC6323170

5. Sarani H, Aghaei N, Saffari M, Akbari Yazdi H. Strategies for Promoting Elders' Health with Sporting Activities: A Qualitative Study. Iranian Journal of Health Education and Health Promotion. 2018;6(4):325-39. https://doi.org/10.30699/acadpub.ijhehp.6.4.325

6. Mahmoudi K, Taghipoor A, Tehrani H, Niat HZ, VahedianShahroodi M. Stages of Behavior Change for Physical Activity in Airport Staff: a quasi-experimental study. Investigacion y educacion en enfermeria. 2020;38(1). https://doi.org/10.17533/udea.iee.v38n1e02 PMid:32124570 PMCid:PMC7871476

7. Aman MS, Mohamed M, Omar-Fauzee M S. Sport for all and elite sport: underlining values and aims for government involvement via leisure policy. European journal of social sciences, 2009; 9(4): 659-668.

8. Goodarzi M, Islami A, Alidoost Ghahfarkhi A. Identification of Factors Affecting the Development of Public Sports Culture through the Islamic Republic of Iran TV. Quarterly Journal of Applied Research in Sports Management, 2016;

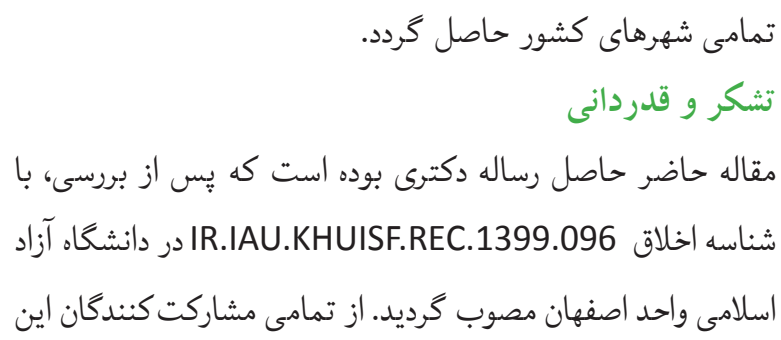

4 (15): 11-27

9. Bahrami S. Media Literacy Education on the attitude of the athletes about sports supplements (Case Study of Kermanshah fitness clubs). Journal of Health Literacy. 2018;3(2):104-12.

10. Saffari M, Ehsani M, Amiri M. An analysis of Iranian public sports using structural equation modeling. Journal of Research in Sports Management and Motor Behavior, 2015; 5 (13): 83-94

11. Ehsani M, Saffari M, Amiri M, Koozehchian H. Design of Iranian public sports model. Sports Management Studies, 2015; 27: 108-78

12. Shahryari N, Tabesh S, Nazari R, Zolfagharzadeh M M. Meta-analysis of the Effects of Social-Health Development on the Institutionalization of sport for all. Nurse and Physician Within War, 2019; 25(7): 41- 48

13. Farajzadeh $S$, Kashef $S$, Behnam M. Identifying the effective factors on capacity building in the sports of Iran. Sport Science. 2020;14(1):72-8

14. Imani M T, Novshadi M R. Qualitative content analysis. Pazhuhesh, 2011; 3(2): 15-44

15. Monsef A, Samati M, Mousavi Madani M. Ranking of eight metropolises of Iran in terms of level of development using the method of hierarchical analysis process and taxonomy in 2011. Eghtesad Tovseh Va Barnamehrizi. 2016; 5 (2): 1-24.

16. Chang Y-W. A comparison of citation contexts between natural sciences and social sciences and humanities. Scientometrics. 2013;96(2):535-53.. https://doi.org/10.1007/s11192-013-0956-1

17. Khaledi Fard A, Ali Doost Ghahfarkhi E, Mahmoudvand Z, Aghaei A, Kab Omir R. Investigating the factors and barriers to participation in public and recreational sports in the Turkish, Kurdish and Lorraine provinces of Iran. New approaches in sports management. 2018; 6 (20): 21-37

18. Piter B. National Program, Knowledge and Innovation in sport and Physical Activity in the Netherlands.Second International Sport for all Conference, Tehran, 2017. 
19. Carvalho Vieira M, Sperandei S, Reis A, da Silva C, Gonçalves T. An analysis of the suitability of public spaces to physical activity practice in Rio de Janeiro Brazil. Preventive Medicine, 2013; 57: 198-200. https://doi.org/10.1016/j.ypmed.2013.05.023 PMid:23732246

20. Fathi, F, Sayadi M A, Seyed Ameri M H. Assessing the need of Urmia citizens for public sports. Applied Research in Sports Management, 2018; 4 (14): 63-74

21. ZJafari M, Zahedi H, Meshkati Z. Comparing the effects of functional, sports vision and concurrent training on static and dynamic balance in elderly women. Journal of Isfahan Medical School. 2015;33(344):1186-96.

22. Samsudin A, Soffian Lee UH, Ishak Y, Ismail A, Said SM, Nor AM. Affective Organizational Commitment as a Mediating Factor for the Leader's Support and Organizational Citizenship Behavior. International Journal of Business \& Management Science. 2018;8(2).

23. Fahlén J, Eliasson I, Wickman K. Resisting self-regulation: An analysis of sport policy programme making and implementation in Sweden. International journal of sport policy and politics. 2015; 3:7(3):391-406. https://doi.org/10.1080/19406940.2014.925954

24. Javadipour M, Sami Nia M. Public sports in Iran and the development of vision, strategy and future plans. Journal of Applied Research in Sports Management. 2013; 15: 1 (4): $21-30$

25. GBull FC. Global advocacy for physical activity-development and progress of the Toronto charter for physical activity: a global call for action. Res Exerc Epidemiol. 2011;13(1):110.

26. Sargit S. Sport Malaysia: Policies and development strategies for the Populace. Second International Sport for all Conference, Tehran, 2017.

27. Tan TC. The Transformation of China's National Fitness Policy: From a Major Sports Country to a World Sports Power. The international journal of the history of sport. 2015; 24;32(8):1071-84. https://doi.org/10.1080/09523367.2015.1036240

28. Heidari M, Saberi A, Kargar, Gh A. Meta-analysis studies and strategies to attract people for the development of public sports in Iran. Research in educational sports, 2018; 6 (14): 111-30

29. Lee WO. The development of citizenship education curriculum in Hong Kong after 1997: Tensions between national identity and global citizenship. Citizenship curriculum in Asia and the Pacific: Springer; 2008. p. 29-42. https://doi.org/10.1007/978-1-4020-8745-5_2 PMCid:PMC2884860

30. Guo X, Hu A, Dai J, Chen D, Zou W, Wang Y. Urbanrural disparity in the satisfaction with public sports services: Survey-based evidence in China. The Social Science Journal, 2018; 1:55(4):455-62. https://doi.org/10.1016/j.soscij.2018.05.003

31. Gray JA, Zimmerman JL, Rimmer JH. Built environment instruments for walkability, bikeability, and recreation: disability and universal design relevant? Disability and Health Journal. 2012; 1:5(2):87-101. https://doi.org/10.1016/j.dhjo.2011.12.002 PMid:22429543

32. Wicker P, Breuer C, Pawlowski T. Promoting sport for all to age-specific target groups: the impact of sport infrastructure. European sport management quarterly. 2009; 1:9(2):103-18. https://doi.org/10.1080/16184740802571377 